\title{
The dominant role of sunlight in degrading winter dissolved organic matter from a thermokarst lake in a subarctic peatland
}

\author{
Flora Mazoyer $^{1,2}$, Isabelle Laurion ${ }^{1,2}$, Milla Rautio ${ }^{2,3}$ \\ ${ }^{1}$ Centre Eau Terre Environnement, Institut National de la Recherche Scientifique, Québec, QC, Canada \\ ${ }^{2}$ Centre for Northern Studies, Université Laval, Québec, QC, Canada \\ ${ }^{3}$ Département des sciences fondamentales, Université du Québec à Chicoutimi, QC, Canada \\ Correspondence to: Flora Mazoyer (mazoyer.flora@gmail.com)
}

\begin{abstract}
Dissolved organic matter (DOM) leaching from thawing permafrost may promote a retroaction loop onto climate if it is efficiently mineralized into greenhouse gases. Yet, many uncertainties remain on the extent of this mineralization, which depends on DOM lability that is seemingly quite variable across landscapes. Thermokarst peatlands are organic-rich systems where some of the largest greenhouse gas (GHG) emission rates have been measured. At spring turnover, anoxic waters are releasing the GHG accumulated in winter, and the DOM pool is being exposed to sunlight. Here, we present an experiment where DOM photo- and bioreactivity were investigated in water collected from a thermokarst lake in a subarctic peatland during late winter (after six months of darkness). We applied treatments with or without light exposure, and manipulated the bacterial abundance with the aim to quantify the unique and combined effects of light and bacteria on DOM reactivity at ice-off in spring. We demonstrate that sunlight was clearly driving the transformation of the DOM pool, partly leading to its full mineralization into $\mathrm{CO}_{2}$. About $18 \%$ of initial dissolved organic carbon (DOC, a loss of $3.9 \mathrm{mgC}$ $\mathrm{L}^{-1}$ ) was directly lost over 18 days of sunlight exposure in a treatment where bacterial abundance was initially reduced by $95 \%$, while dark incubations lead to very limited changes in DOC, regardless of the bacterial abundance and activity. The highest DOC loss was observed for the treatment with the full bacterial community exposed to sunlight (5.0 $\mathrm{mgC} \mathrm{L}^{-1}$ ), indicating an undirect effect of light through the bacterial consumption of photoproducts. Sunlight was an outstanding boosting factor on bacterial growth when grazers were eliminated, leading to the recovery of the original bacterial abundance in about 8 days. The results also show that only half of the lightassociated DOC losses were converted into $\mathrm{CO}_{2}$, with the rest potentially turned into particles through photoflocculation. Sunlight should therefore play a major role in $\mathrm{DOM}$ processing, $\mathrm{CO}_{2}$ production and carbon burial in peatland lakes during spring, likely lasting for the rest of the open-season in mixing surface layers.
\end{abstract}

\section{Introduction}

In northern regions, permafrost soil temperature is slowly increasing in response to climate change (Biskaborn et al., 2019), leading to permafrost thawing that has many consequences on biogeochemical cycles. Thawing affects the morphology of existing water bodies, and generates new ones through soil subsidence and erosion (Vonk et al., 2015). When previously-frozen carbon stocks are mineralized into greenhouse gases, emissions could feed a climatic retroaction loop (Schuur et al., 2015), making the fate of this large pool of wide interest.

It is well established that freshwaters are a key component of the global carbon budget (Cole et al., 2007), and that carbon dioxide $\left(\mathrm{CO}_{2}\right)$ emissions from lakes are tightly linked to organic carbon inputs (Sobek et al., 2005). More 
recently, northern lakes were shown to be a significant part of the carbon cycle dynamic (Wik et al., 2016). The widespread thermokarst features created by abrupt thawing of ice-rich permafrost are particularly considered as hot spots of greenhouse gas emissions (e.g. Cory et al., 2013; Matveev et al., 2016). Olefeldt et al. (2016) estimated that peatland thermokarst landscapes cover $8 \%$ of the northern circumpolar permafrost area, and contain $15 \%$ of all organic carbon within the 0-3 m depth soil layer. Future changes in northern peatlands and the fate of these organic carbon stocks under warming thus deserve attention.

Mineralization of dissolved organic matter (DOM) is a major pathway of $\mathrm{CO}_{2}$ emissions in inland waters, and is regulated by two processes: bacterial respiration and sunlight oxidation (photooxidation). To estimate the respective shares of these phenomena or their importance at the scale of a lake or a region is a complex task, especially as they can influence each other (e.g. Obernosterer and Benner, 2004) and are constantly changing over space and time (reviewed by Cory and Kling, 2018). Seasonal variations in $\mathrm{CO}_{2}$ emission rates have been studied in various types of northern lentic ecosystems (Elder et al., 2018; Hughes-Allen et al., 2021; Prèskienis et al., 2021; Sepulveda-Jauregui et al., 2015), underlining the importance of collecting data on a complete annual cycle. Because the summer season offers easier conditions for sampling and instrument handling, most studies of northern lakes have occurred during this period (Block et al., 2019). The long ice-covered winter and the short ice-breaking spring seasons have historically been overlooked by limnologists, although many northern lakes are covered by ice for several months (Hampton et al., 2017). In fact, recent studies demonstrate that carbon dynamics during winter and at ice-break are far from negligible. The review by Denfeld et al. (2018), presenting results on boreal lakes from Scandinavia and North America, evaluated that $17 \%$ of annual $\mathrm{CO}_{2}$ emissions happened at the icebreak period, while the study from Jansen et al. (2019) reports up to $30 \%$. These emissions would mainly result from a fast release of gases accumulated under the ice over the winter season, and from DOM photomineralization that is particularly intense at spring (Vachon et al., 2016, 2017). In northern lakes, sunlight was responsible for up to $49 \%$ of DOM mineralisation at spring time, in comparison to only $14 \%$ during the open water season (Vachon et al., 2016). The concept of DOM photoreactivity appears to be particularly central to explain these seasonal or temporal differences (Groeneveld et al., 2016; Pickard et al., 2017).

The goal of our study was to experimentally explore the photoreactivity and bioreactivity of late-winter DOM collected from a thermokarstic lake located in a subarctic peatland of eastern Canada. This work is a contribution on learning about carbon cycling in northern organic-rich lakes during the critical ice-off transition period when DOM that was microbially processed during the winter becomes exposed to sunlight in surface layers. Winter DOM reactivity has been identified as a major knowledge gap in carbon biogeochemistry research (Hampton et al., 2017). The objectives were to assess the effects of sunlight on DOM properties, microbial dynamics and carbon biogeochemistry, as compared to dark processing. We hypothesized that sunlight would have a dominant effect on DOM degradation and mineralization after the long subarctic winter, and a positive effect on bacterial metabolism through the phototransformation of aromatic compounds. We tested this through outdoor incubations where DOM properties, $\mathrm{CO}_{2}$ concentration, bacterial abundance and bacterial production were followed in replicated microcosms over 18 days.

\section{Material and methods}




\subsection{Study site}

The study site was located on the eastern shore of Hudson Bay, $8 \mathrm{~km}$ southwest of the village of Whapmagoostui-

Kuujjuarapik, Nunavik (Quebec, Canada), in the peatland valley of the Sasapimakwananisikw River, hereafter referred as the SAS valley. The historical development of this subarctic palsa site has been reconstructed through palaeoecology in Arlen-Pouliot and Bhiry (2005). Peat accumulation over the marine clay bed started shortly after $6000 \mathrm{cal}$. BP and interrupted $400 \mathrm{cal}$. BP with the Little Ice Age. During this cooling period, permafrost established on this ombrotrophic bog and caused the uplifting of palsas (round-shaped mounds). Since about 100 years, temperature and precipitation have increased again, leading to permafrost thaw, palsa collapse, and thermokarst lake formation. These black-coloured water bodies lay in a peat bog mainly colonized by ericaceous shrubs, semiaquatic plants such as Carex aquatilis, Sphagnum sp. and brown mosses (Bhiry et al., 2011). Nowadays, permafrost in the SAS valley underlies less than $2 \%$ of the land surface, and gathers in the core of the scattered palsa mounds (Bhiry et al., 2011). Detailed landscape diagram and picture can be found in Figure 7 of Vincent et al. (2017).

\subsection{Field sampling and in situ measurements}

Sampling was carried out between the 19 and 24 March 2016 in a thermokarst lake named SAS2A, with an area of $196 \mathrm{~m}^{2}$ and a maximum depth of $2.8 \mathrm{~m}\left(55.225018^{\circ} \mathrm{N}, 77.696580^{\circ} \mathrm{W}\right)$. More information about this well-studied lake, along with a description of the winter sampling campaign, are further reported in Matveev et al. (2019). The lake was covered with $0.5 \mathrm{~m}$ of snow and $0.6 \mathrm{~m}$ of ice, underlain with a water column of about $1.7 \mathrm{~m}$, which was entirely anoxic. At this time of the year, temperature varied between $0.5^{\circ} \mathrm{C}$ (immediately below the ice) and $1.9^{\circ} \mathrm{C}$ (bottom). Despite this thermal stratification, DOM properties were similar through the water column: DOC varied between 18.3 and $20.9 \mathrm{mgC} \mathrm{L}^{-1}$, SUVA between 6.78 and $6.85 \mathrm{~L} \mathrm{mgC}^{-1} \mathrm{~m}^{-1}$, and $\mathrm{S}_{285}$ between 0.0111 and 0.0105 $\mathrm{nm}^{-1}$ (Table S1). Water for the experiment was collected on 24 March at the surface just below the ice cover, and stored in a $10-\mathrm{L}$ carboy.

\subsection{Experimental setup}

In this paper we use the term bacteria for simplicity, to refer to any heterotrophic planktonic microorganisms affecting the DOM pool with a maximum size of about $3 \mu \mathrm{m}$, which may include archaea, phototrophic eukaryotes and small protozoans. On the other hand, cell counts obtained by flow cytometry only comprise cells smaller than about $1 \mu \mathrm{m}$ (see section on bacterial abundance below). Also, the term light used hereafter refers to sunlight wavelengths involved in photooxidation, thus it includes ultraviolet radiation and not only visible radiation.

The experiment was set up approximately four months after the water was collected in the field, on the roof of the INRS in Quebec City $\left(46.812899^{\circ} \mathrm{N}, 71.223821^{\circ} \mathrm{W}\right.$ in Quebec, Canada). Since the ice cover completely disappeared from the sampled lake only on 30 May (Matveev et al., 2019), and the collected water was kept in the dark at $4{ }^{\circ} \mathrm{C}$ similar to under-ice conditions, it seems reasonable to consider that there was only a delay of about two months before the collected water was exposed to sunlight as compared to the natural conditions (after a winter lasting 7.5 months). Indeed, DOM variables did not change extensively between water collection and the beginning of the experiment (see Table S1 to compare with Table 1: small increases in dissolved organic carbon (DOC) and fluorescing DOM, small decreases in chromophoric DOM and aromaticity). Moreover, in situ data demonstrate that the collected water was well representing the whole water column (Table S1). 
Table 1. Water characteristics at the start of the incubation (T0), before applying the different treatments (letter $\mathrm{L}$ means with sunlight; letter B means with the original bacterial community; treatments B, C and PI were incubated in the dark). Characteristics include dissolved organic carbon (DOC), dissolved inorganic carbon (DIC), absorption coefficient of DOM at $320 \mathrm{~nm}\left(\mathbf{a}_{320}\right)$, specific absorbance index at $254 \mathrm{~nm}\left(\mathbf{S U V A}_{254}\right)$, absorption slope at $285 \mathrm{~nm}\left(\mathbf{S}_{285}\right)$, total fluorescence by DOM ( $\mathrm{F}_{\text {tot }}$ as the sum of the 5 components) and its proportion into C1-C5 components, total bacterial abundance (BA), and the bacteria production rate (BP). Variables are given as the triplicate mean \pm standard error.

\begin{tabular}{|c|c|c|c|}
\hline & $\begin{array}{l}\text { Water with the original } \\
\text { bacterial community* }\end{array}$ & $\begin{array}{c}\text { Bacteria-filtered } \\
\text { waterं }\end{array}$ & $\begin{array}{l}\text { Pre-incubated water } \\
\text { inoculated } \ddagger\end{array}$ \\
\hline Associated treatments & BL, B & $\mathrm{L}, \mathrm{C}$ & PI \\
\hline $\mathrm{DOC}\left(\mathrm{mgC} \mathrm{L}^{-1}\right)$ & $22.1 \pm 0.7$ & $21.9 \pm 0.7$ & $19.8 \pm 0.2$ \\
\hline DIC (mM) & $0.32 \pm 0.01$ & $0.25 \pm 0.01$ & $0.29 \pm 0.01$ \\
\hline$a_{320}\left(m^{-1}\right)$ & $119 \pm 0.2$ & $115 \pm 0.5$ & $99 \pm 0.9$ \\
\hline $\operatorname{SUVA}_{254}\left(\mathrm{~L} \mathrm{mgC}^{-1} \mathrm{~m}^{-1}\right)$ & $4.68 \pm 0.14$ & $4.56 \pm 0.13$ & $4.67 \pm 0.3$ \\
\hline $\mathrm{S}_{285}\left(\mathrm{~nm}^{-1}\right)$ & $0.0100 \pm 10^{-5}$ & $0.0100 \pm 10^{-5}$ & $0.0110 \pm 10^{-5}$ \\
\hline $\mathrm{F}_{\text {tot }}(\mathrm{RU})$ & $8.2 \pm 0.01$ & $8.2 \pm 0.05$ & $6.5 \pm 0.02$ \\
\hline $\mathrm{C} 1(\mathrm{RU}) / \%$ of $\mathrm{F}_{\mathrm{tot}}$ & $2.8 / 34$ & $2.8 / 34$ & $2.3 / 35$ \\
\hline $\mathrm{C} 2(\mathrm{RU}) / \%$ of $\mathrm{F}_{\mathrm{tot}}$ & $2.0 / 24$ & $2.0 / 24$ & $1.8 / 28$ \\
\hline $\mathrm{C} 3(\mathrm{RU}) / \%$ of $\mathrm{F}_{\mathrm{tot}}$ & $1.6 / 19$ & $1.6 / 19$ & $0.9 / 14$ \\
\hline $\mathrm{C} 4(\mathrm{RU}) / \%$ of $\mathrm{F}_{\mathrm{tot}}$ & $1.2 / 15$ & $1.2 / 15$ & $1.2 / 18$ \\
\hline $\mathrm{C} 5(\mathrm{RU}) / \%$ of $\mathrm{F}_{\mathrm{tot}}$ & $0.7 / 9$ & $0.7 / 9$ & $0.4 / 6$ \\
\hline $\mathrm{BA}\left(10^{5}\right.$ cells $\left.\mathrm{mL}^{-1}\right)$ & $13.02 \pm 2.26$ & $0.69 \pm 0.18$ & $1.95 \pm 0.26$ \\
\hline $\mathrm{BP}\left(\mu g \mathrm{C} \mathrm{L}^{-1} \mathrm{~h}^{-1}\right)$ & $0.224 \pm 0.017$ & $0.003 \pm 0.001$ & $0.015 \pm 0.001$ \\
\hline
\end{tabular}

*Filtration with nominal $1.5 \mu \mathrm{m}$ glass fiber filters to remove most grazers. $†$ Filtration with $0.2 \mu \mathrm{m}$ filters to remove most bacteria (95\%) and all grazers; $\$$ Pre-filtration with $0.2 \mu \mathrm{m}$ filters for a 2-days incubation under sunlight, followed by the inoculation with $3-\mu \mathrm{m}$ filtered water at a volumetric ratio of $10 \%$ and incubated in the dark.

120

The preparation of the experiment started with series of filtration steps to generate two types of water, one containing the original bacterial community $(1.5-\mu \mathrm{m}$ filtered) and the other with a largely reduced bacterial abundance $(0.2-\mu \mathrm{m}$ filtered). Sterility was aimed but flow cytometry results later indicated that the original abundance was only reduced by $95 \%$. The filtration steps included pre-filtration through 64 and $5 \mu \mathrm{m}$ sieves using Milli-Q rinsed NITEX®, followed by filtration through pre-combusted $1.5-\mu \mathrm{m}$ glass fibre filters (VWR®, nominal porosity) to remove heterotrophic nanoflagellates and non-living particles. The study from del Giorgio and Bouvier (2002) reported that 1- $\mu \mathrm{m}$ glass fibre filters show good results for that purpose. Part of this water was kept for the incubations with bacteria, and the rest was subsequently passed through a sterile $0.2-\mu \mathrm{m}$ capsule filter (HT Tuffryn ${ }^{\circledR}$ polysulfone membrane, Pall Corp.), or applying a double filtration step using pre-combusted $0.7-\mu \mathrm{m}$ glass fibre filters (GF75, nominal porosity, Advantec $($ ) and pre-rinsed $0.2-\mu \mathrm{m}$ cellulose acetate filters (Advantec $®$ ) to remove bacteria.

These two types of waters were exposed to natural sunlight or dark conditions on the roof of the laboratory during 18 days from 30 July to 17 August. Five treatments were aimed from various combinations of "bacteria" and "light". In four of them, these factors were applied simultaneously: with bacteria and light (hereafter BL), with bacteria in the dark (B), bacteria-filtered with light (L), and bacteria-filtered in the dark (C, for control). The fifth treatment was applied in a consecutive manner: a portion of the bacteria-filtered water was pre-incubated under natural sunlight for two days (approximately $42.6 \mathrm{MJ} \mathrm{m}^{-2}$ received in total), and then inoculated with bacteria for an incubation in the dark (PI, for pre-incubated). The goal of this last treatment was to uncouple the effect of sunlight from the microbial degradation processes. The bacterial inoculation was done using original lake water filtrated through 3- $\mu \mathrm{m}$ polycarbonate filters (PCTE membrane, Advantec ${ }^{\circledR}$ ), and using a volumetric ratio of $10 \%$. 
The choice of using 3- $\mu \mathrm{m}$ filters (made for logistical reasons) was considered fairly close to using nominal 1.5$\mu \mathrm{m}$ filters as for B and BL treatments. Overall, the preparation of the experiment lasted about a week, during which water was systematically kept in the dark at $4^{\circ} \mathrm{C}$.

Water incubation was carried out in $60 \mathrm{~mL}$ transparent FEP Teflon bottles (Nalgene ${ }^{\text {) }}$, a material known for its transparency to ultraviolet and visible radiation despite its diffusive property. Twelve bottles per treatment were filled to the rim and incubated, allowing to sacrifice triplicate bottles at days 3, 8, 13 and 18. Dark treatment bottles were wrapped in opaque tape. Bottles were all immersed at the same time in a tray placed on the roof top. The tray was equipped at the bottom with a twisted copper pipe connected to a circulating bath aiming at limiting large increase of temperature during sunny days and tempering day-night differences. The tray was filled with tap water (added daily to offset evaporative losses), and oriented to maximize sunlight exposure, with bottles moved daily to limit unequal shading. Three light and temperature loggers (HOBO Pendant ${ }^{\circledR}$, ONSET) were installed at the same depth as the bottles to obtain a relative index of incoming sunlight, with one wrapped as in the dark treatment to control for temperature difference among treatments. Temperature in the light averaged $19.7^{\circ} \mathrm{C}$ (ranging from 8.5 to $34.3^{\circ} \mathrm{C}$ ) as compared to $18.9^{\circ} \mathrm{C}\left(8.4\right.$ to $\left.32.0^{\circ} \mathrm{C}\right)$ in the dark (Fig. S1 a). These temperatures were higher than the ones measured in SAS2A at the spring ice-break, but averages were similar to temperatures measured at the pond surface in summer (Matveev et al., 2019).

Time zero (T0 - at day 0) measurements were taken from the three types of water: water containing the original bacterial community (BL and B), the bacteria-filtered water ( $\mathrm{L}$ and $\mathrm{C}$ ) and the inoculated pre-incubated water (PI). They were the only pseudo-replicates from the dataset (i.e., 3 samples taken from the same container, as opposed to 3 replicate bottles for days 3, 8, 13 and 18). At each time step, we measured DOC, dissolved inorganic carbon (DIC), chromophoric dissolved organic matter (CDOM, absorption spectra), fluorescing dissolved organic matter (FDOM, excitation-emission matrices) and bacterial abundance. Bacterial production was only measured at T0, day 8 and day 18 .

\subsection{Incoming radiation during the experiment}

Radiation during the incubation was measured every 2 minutes in a weather station (Wireless Vantage Pro2 $2^{\mathrm{TM}}$ Plus, Davis Instrument Corporation) installed on Laval University campus (http://meteolaval.gel.ulaval.ca/meteocam-proxy.php) at a distance of $5.4 \mathrm{~km}$ from INRS (pyranometer integration from 300 to $1100 \mathrm{~nm}$ ). Missing data during the first three days were estimated through a linear regression between the station irradiance and our Pendant logger values. Hourly radiation measured at the SILA station of WhapmagoostuiKuujjuarapik in 2015 and 2016 (on the shore of Hudson Bay, $8 \mathrm{~km}$ away from the study site, pyranometer integration from 300 to $2800 \mathrm{~nm}$; CEN, 2020a) and at the SAS study site from 2017 to 2019 (local radiation unavailable before 2017, same pyranometer; CEN, 2020b) were integrated over the incubation period (18 days in August). They were compared to get a sense of incoming sunlight energy at both latitudes (Fig. S1 b). Total incoming sunlight energy was 33 to $103 \%$ higher in Quebec City (349 $\mathrm{MJ} \mathrm{m}^{-2}$ ) than at SAS site (from 172 to 263 $\mathrm{MJ} \mathrm{m}^{-2}$ ), but similar to the sunlight energy recorded at the SILA station (309 and $342 \mathrm{MJ} \mathrm{m}^{-2}$ ). 


\subsection{DIC analysis}

The production of dissolved $\mathrm{CO}_{2}$, as a measure of bacterial respiration and DOM photomineralization, was estimated through changes in DIC concentration, assuming that any increase in DIC over time within the incubation bottles corresponded to a production of $\mathrm{CO}_{2}$. Exetainer ${ }^{\circledR}$ vials $(12 \mathrm{~mL}$, Labco) were prepared beforehand by adding $120 \mu \mathrm{L}$ of $10 \% \mathrm{HCl}$, and manually purging with gaseous nitrogen for one minute. Quickly after opening the incubation bottle, $3 \mathrm{~mL}$ of water was gently sampled with a syringe and injected with a $21 \mathrm{G}$ needle through the septum of a prepared vial. The vial headspace was analysed by gas chromatography within two months (TRACE ${ }^{\text {TM }} 1310$ GC Greenhouse, Thermo Fisher Scientific, Molecular Sieve column 5A 80/100 6' x $1 / 16$ ", thermal conductivity and flame ionisation detectors, calibration curve made with carbonate solutions 0-2.5 $\mathrm{mM}$ ). Vials were weighted at each step to convert masses to volumes, and DIC was calculated as following Eq. (1):

$[D I C]=\frac{\left[\mathrm{CO}_{2}(g)\right] \times\left(V_{\text {vial }}-V_{\text {gas }}+1.2 \times V_{\text {gas }}\right)}{1.2 \times V_{\text {sample }}}$,

where [DIC] is DIC concentration in $\mathrm{mM},\left[\mathrm{CO}_{2}(\mathrm{~g})\right]$ the concentration of $\mathrm{CO}_{2}$ contained into the gaseous phase in $\mathrm{mM}, \mathrm{V}_{\text {vial }}$ the vial volume in $\mathrm{mL}, \mathrm{V}_{\text {gas }}$ the gas volume contained in the vial in $\mathrm{mL}$, and $\mathrm{V}_{\text {sample }}$ the sample volume added to the vial in $\mathrm{mL}$. The value of 1.2 is the Henry's law volatility constant $\mathrm{K}_{\mathrm{H}}$ for $\mathrm{CO}_{2}$.

\subsection{DOM analyses}

Water samples were filtered onto $0.45-\mu \mathrm{m}$ polyethersulfone syringe filters (AMD Manufacturing Inc.) and stored in 40 -mL glass vials at $4^{\circ} \mathrm{C}$. Part of this water was used to perform the optical analyses within $24 \mathrm{~h}$ after sampling, and the rest was stored for later DOC analysis (within 2 months) on a Total Organic Carbon analyser (Aurora $1030 \mathrm{~W}$, O.I. Analytical) using the persulfate oxidation method (precision $<5 \%$, detection limit $0.1 \mathrm{mg} \mathrm{L}^{-1}$ ).

CDOM absorbance scans between 200 and $800 \mathrm{~nm}$ on samples brought at room temperature were obtained with a dual beam spectrophotometer ( $2 \mathrm{~nm}$ slits, scan speed $200 \mathrm{~nm} \mathrm{~min}{ }^{-1}$, Cary 100 Bio, Varian) using a 1-cm path quartz cuvette. The null-point adjustment was applied on blank-corrected absorbance spectra using the mean value from 790 to $800 \mathrm{~nm}$, and data were converted to Napierian absorption coefficients (in $\mathrm{m}^{-1}$ ). The absorption coefficient at $320 \mathrm{~nm}$ (hereafter, $\mathrm{a}_{320}$ ) is used as a proxy for CDOM quantification. The specific absorbance at 254 $\mathrm{nm}\left(\mathrm{SUVA}_{254}\right.$ ), calculated following Weishaar et al. (2003), is used as a proxy for the aromatic content of DOM. The spectral slope between 275 and $295 \mathrm{~nm}\left(\mathrm{~S}_{285}\right.$, in $\left.\mathrm{nm}^{-1}\right)$, as a linear fit on log-transformed data, was also calculated, commonly used as an indicator of the mean size of DOM molecules (Helms et al., 2008).

Fluorescence excitation-emission matrices (EEMs) were obtained on a spectrofluorometer (Cary Eclipse, Varian) across an excitation waveband from 240 to $450 \mathrm{~nm}$ (10 nm increment), and an emission waveband from 300 to $560 \mathrm{~nm}$ ( $2 \mathrm{~nm}$ increment). DOM was characterized by the extraction of fluorescent components using the parallel factor analysis (PARAFAC) developed by Stedmon et al. (2003). Blank-subtracted EEMs were corrected for innerfilter effect using absorbance spectra and standardized to Raman units (RU), after which the Raman and Rayleigh scatter peaks were excised. All pre-processing was done with the FDOMcorr toolbox for Matlab (version 1.4,

Murphy et al., 2010), and the model was created using the drEEM toolbox (version 0.1.0, Murphy et al., 2013). The dataset contained 114 samples: 60 from the current experiment, plus 54 from another experiment carried out 
on summer and winter water from the same pond (unpublished data). A 5-component model was validated using split-half analysis, and the residuals did not present any obvious peak signals.

Fluorescence components $\mathrm{C} 1$ to $\mathrm{C} 5$ were expressed as the maximum fluorescence intensity at the peak in RU. The total fluorescence $\left(\mathrm{F}_{\mathrm{tot}}\right)$ was obtained by summing the fluorescence of all 5 components, and used to calculate their relative abundance. The identification of the components was done in the Openfluor database of Murphy et al. (2014) through the selection of similar spectra with a Tucker congruence coefficient (TCC) exceeding 0.95 on the excitation and emission spectra simultaneously. Unfortunately, the EEMs from T0 could not be exploited (related to an acquisition problem). However, based on CDOM dynamics from T0 and FDOM dynamics from T3 (see results), we reasonably estimated the initial values of treatments B, C and PI to be the same as at T3, and the initial values of $\mathrm{BL}$ and $\mathrm{L}$ to be similar to the ones of $\mathrm{B}$ and $\mathrm{C}$, respectively. These values were therefore used to calculate temporal changes and make statistics hereafter.

\subsection{Bacterial abundance and production}

Bacterial abundance (BA) was obtained on water samples fixed with glutaraldehyde (1\% final concentration), snap-frozen with liquid nitrogen, and kept at $-80^{\circ} \mathrm{C}$ until analysed with a flow cytometer (Accuri C6 Plus, BD Biosciences). Before counting, the samples were unfrozen at $4{ }^{\circ} \mathrm{C}$ overnight and then brought to room temperature. Cells were stained with SYBR Green I (2.5X final concentration) for 15 minutes in the dark. Data were acquired at the slowest flow rate, with speed measured daily using Trucount ${ }^{\mathrm{TM}}$ absolute counting tubes (mean of $0.43 \mu \mathrm{L}$ $\mathrm{sec}^{-1}$ over the analytical period). Yellow-green Fluoresbrite ${ }^{\circledR}$ microspheres of $1 \mu \mathrm{m}$ diameter (Polysciences Inc.) were added directly to Trucount tubes as an internal size standard and to control gate positions. Cells were discriminated on a log-scale using green fluorescence and forward-scatter for a blue laser excitation. One acquisition was done for each sample at a maximum rate of 1000 events $\mathrm{sec}^{-1}$ and with a minimum of 10000 events counted. Gating was refined considering all samples in order to extract their population abundance using the same gates (Fig. S4). The presence of phytoplankton cells was checked in samples exposed to sunlight using cytometer runs done without staining with SYBR Green and looking at fluorescence from chlorophyll-a or phycocyanin, but no population could be discriminated from the noise. Samples were analysed before and after sonification (Sonifier® SFX150, Branson тм, $30 \mathrm{sec}$. with pulses of $0.1 \mathrm{sec}$./sec. at $50 \%$ duty cycle, $\sim$ equivalent to $10 \mathrm{~W}$ ) to evaluate the relative proportion of particle-attached and free-living bacteria. The sonication rod was directly introduced into the acquisition tubes placed in an ice bath.

240 Bacterial production (BP) was measured using the tritiated leucine incorporation method (Kirchman et al., 1985), with centrifugation improvement proposed by Smith and Azam (1992). Production assays started less than 3 hours after sampling. A working solution with a specific activity of $150 \mathrm{Ci} \mathrm{mmol}^{-1}$ was added to triplicate aliquots, each containing $1.2 \mathrm{~mL}$ of sample water (final leucine concentration of $30 \mathrm{nM}$ ). Incubations for 2 hours in the dark at room temperature $\left(\sim 21^{\circ} \mathrm{C}\right)$ were ended with the addition of trichloroacetic acid (TCA, $5 \%$ final concentration). For each triplicate, one additional tube was fixed with TCA at the beginning of the incubation to account for passive incorporation of tritiated leucine by cells. The tracer concentration and incubation duration were based on previous studies on thermokarst lakes near the sampling site (Roiha et al., 2015). Tubes were then stored at $-20^{\circ} \mathrm{C}$ until analysis. Samples were unfrozen at room temperature, centrifuged 10 minutes at $16000 \mathrm{~g}$, and the pellet rinsed 2 times with 5\% TCA solution. Scintillation cocktail (Ecolite $(+)^{\mathrm{TM}}$, MP Biomedicals) was added for at least 
24 hours before counting with a liquid scintillation analyser (Tri-Carb® 2910TR, Perkin Elmer). Counts per minute were corrected with controls and converted into disintegration per minute (DPM) using the counting efficiency calculated from home-made standards. Sample aliquots acting as controls were prepared with the same steps described above but without adding the tracer solution, while standards were aliquots with a known amount of radioactive leucine. Calculation details on $\mathrm{BP}$ can be found in the supplementary information.

\subsection{Data analysis}

The experimental design was analysed with ANOVAs excluding T0 values. Effects and interactions among BL, B, L and C treatments were examined with a 3-way ANOVA testing for light (2 levels, fixed), bacteria (2 levels, fixed) and time (4 levels, fixed) on each variable. PI treatment was not included in this analysis due to its distinct preparation method, but it was compared to the other treatments separately using a 2-way ANOVA testing for treatments (5 levels, fixed) and time (4 levels, fixed). ANOVA assumptions were checked by graphical examination of the residuals plotted against the expected values. Except for $\mathrm{C} 5$, all variables were transformed to validate assumptions of the ANOVA. A log-transformation was applied to $S_{285}$, while all remaining variables were transformed with square root. When a term of the ANOVA was significant, comparison between the different levels was obtained using Tukey's Honestly Significant Difference posthoc test. A significance level of $\alpha=0.05$ was used for all statistical analysis. The $95 \%$ confidence interval around T0 values were calculated and represented in the figures as a thin bar on the left side of T0. Values falling outside this interval during the incubation were considered as significantly different from T0. ANOVAs were performed with JMP 15.0 software, while the rest of the statistical analyses and graphs were done on RStudio 1.2.5 software.

\section{Results}

\subsection{Initial characteristics of incubated waters}

At T0, DOM properties between waters with or without bacteria were similar, showing that the filtration step did not affect DOM composition (Table 1). As expected, bacterial abundance and production were much higher in the water containing the initial bacterial community, with 19 times more free bacterial cells, and 75 times higher production rate (BP normalized by BA was also 4 times higher on average). Despite our sterilization efforts relying on $0.2-\mu \mathrm{m}$ filtration, approximately 70000 cells per $\mathrm{mL}$ remained in the bacteria-filtered water (i.e. $5 \%$ of the original abundance). This implies that $\mathrm{L}$ and $\mathrm{C}$ treatments were not completely sterile, but this filtration step apparently removed all protists (see below).

The pre-incubated water (PI treatment) displayed different values for all variables except $\mathrm{SUVA}_{254}$ as compared to the two other T0 water types, which was expected after an exposition to sunlight for 3 days. DOC, $\mathrm{a}_{320}$ and $\mathrm{F}_{\text {tot }}$ were lower than for the two other waters, while $S_{285}$ was higher (Table 1). There had been an increase of DIC during the pre-treatment with light (by approx. 16\%) when comparing values with those in bacteria-filtered water from which PI treatment water was prepared (this cannot be seen in Fig. 1 since DIC at T0 was subtracted from all values). Bacterial abundance and production were also higher in PI than in C treatment, showing the effect of the bacterial inoculation, but remained considerably lower than in the water containing the original bacterial community. The five fluorescent components were less abundant in the pre-incubated water than in the two other 


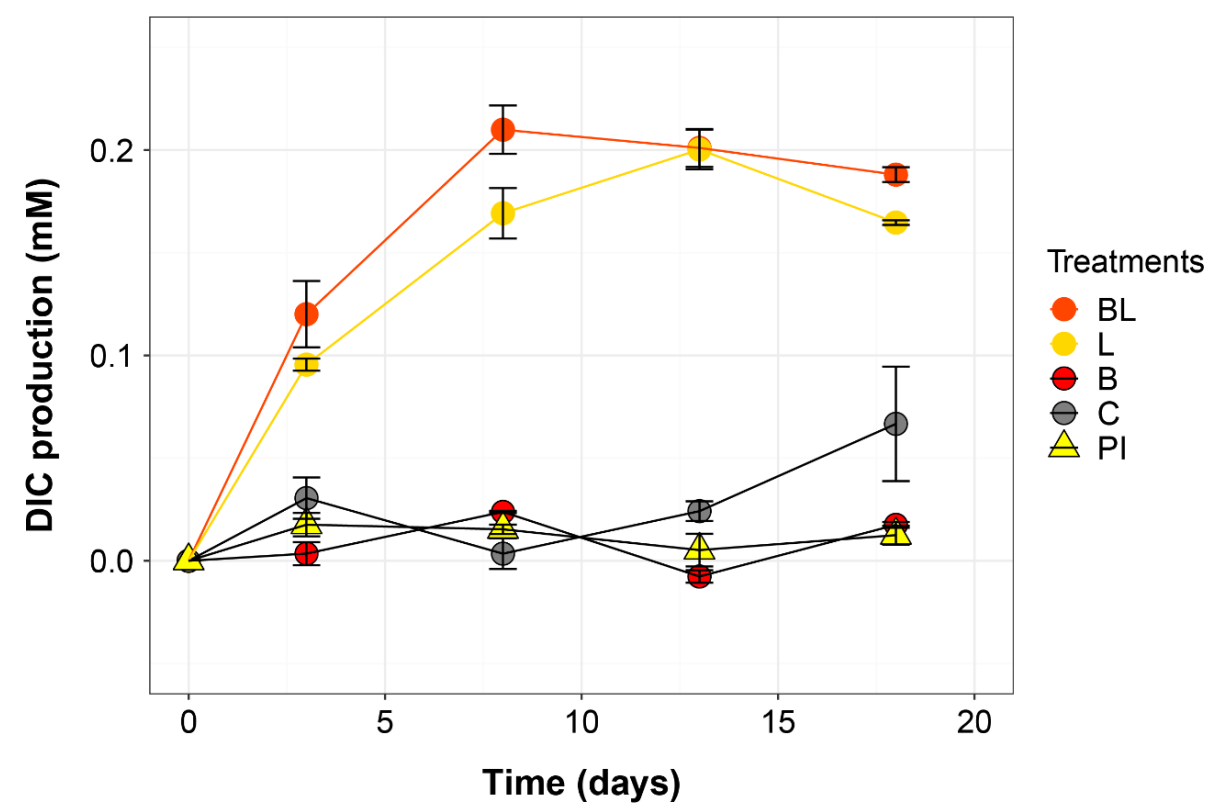

Figure 1. Temporal dynamics in dissolved inorganic carbon (DIC), presented as the difference from the mean value at time zero for each treatment (i.e. the DIC produced during the incubation). Error bars represent the standard errors. Treatments are as follows: $\mathrm{BL}=$ water with original bacterial community exposed to light, $\mathrm{L}=$ bacteria-filtered water exposed to light, $\mathrm{B}=$ water with original bacteria incubated in the dark, $\mathrm{C}=$ bacteria-filtered water incubated in the dark, and PI = pre-incubated water inoculated with bacteria and incubated in the dark.

All five DOM components were identified as humic-like, with maximum emission peak above $400 \mathrm{~nm}$ (Table S2

and Fig. S2). C1 is broadly described as a common ubiquitous group of fluorophores with a terrestrial origin. C2 was most probably of terrestrial origin (found dominant in wetland and forest drainage waters) and described as bio-refractory. Component $\mathrm{C} 3$ showed the longest and broadest excitation band, along with the longest emission peak, suggesting that it belongs to a particularly high-molecular weight fraction of terrestrial humic matter (Stedmon et al., 2003). It was reported in very diverse environments and usually assigned to a terrestrial origin, but some studies assigned it to an autochthonous origin. Murphy et al. (2018) demonstrated that humic-like components from terrestrial and autochthonous sources could display similar spectra and chemical characteristics, thus highlighting the uncertainty related to the origin of fluorescing components. Finally, even though the origin of $\mathrm{C} 4$ and $\mathrm{C} 5$ is uncertain, they could be characterized by their photodegradability.

\subsection{Changes in chemical and optical variables during the incubation}

The largest changes in DIC, DOC and various CDOM properties were observed for the light treatments BL and L (complete ANOVA results presented in Table S3). DIC (Fig. 1) significantly accumulated in bottles in both light treatments until day 8 (posthoc, $\mathrm{P}<0.0001$ ), at respective rates of 0.025 and $0.020 \mathrm{mM} \mathrm{day}^{-1}$, after which it remained stable (posthoc, $\mathrm{P}>0.97$ ). Correspondingly, concentrations in DOC and CDOM (Fig. 2, with $\mathrm{a}_{320}$ as a 
https://doi.org/10.5194/bg-2022-26

Preprint. Discussion started: 28 January 2022

(c) Author(s) 2022. CC BY 4.0 License.

proxy for CDOM concentration) significantly decreased with light, with total losses of $6.7 \mathrm{mgC} \mathrm{L}^{-1}$ (by $30 \%$ ) and

$47 \mathrm{~m}^{-1}(40 \%)$ for BL, and $5.6 \mathrm{mgC} \mathrm{L}^{-1}(25 \%)$ and $45 \mathrm{~m}^{-1}(39 \%)$ for $\mathrm{L}$ after 18 days of incubation.
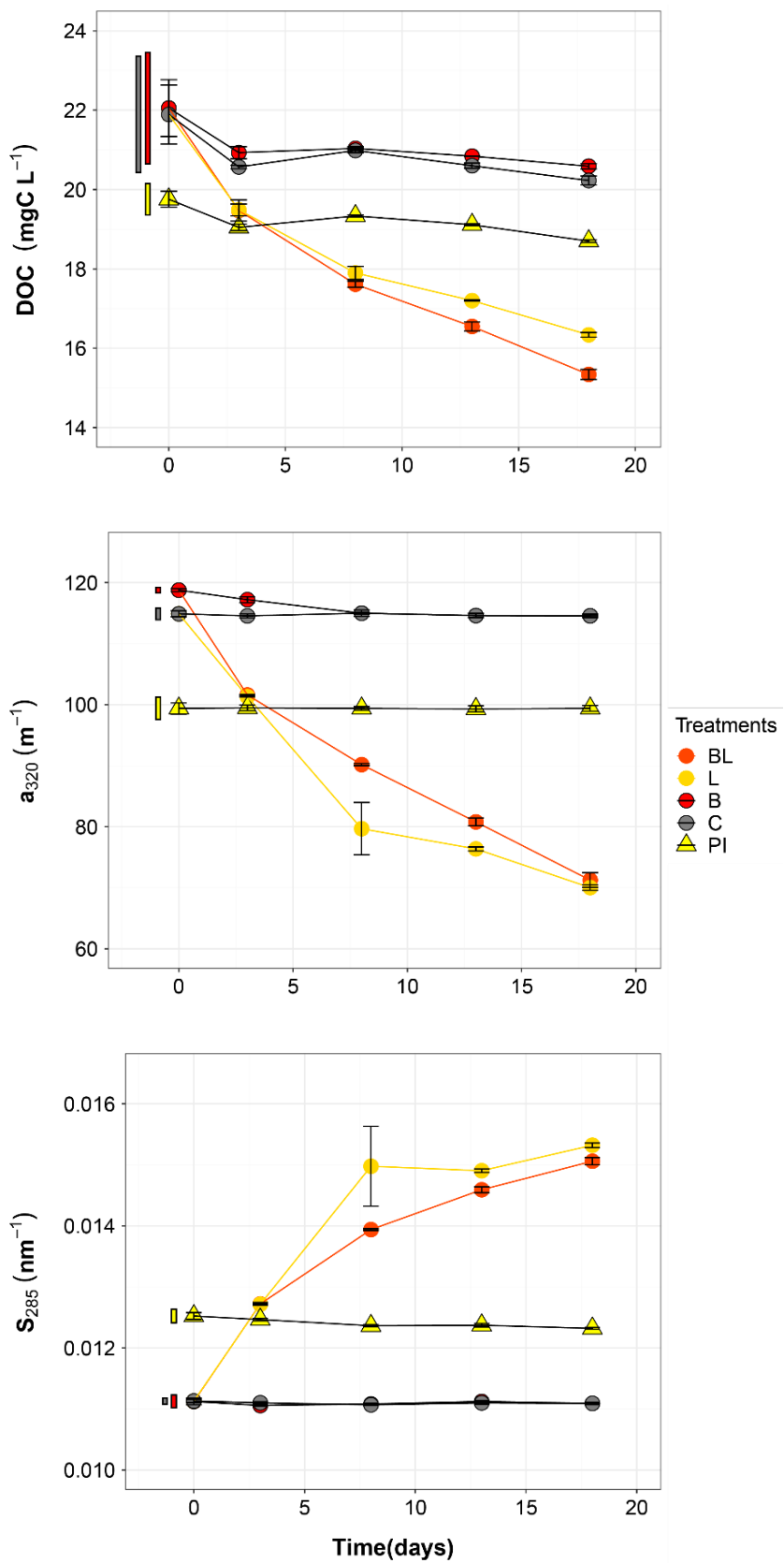

Figure 2. Temporal dynamics of the dissolved organic carbon (DOC), the absorption coefficient at $320 \mathrm{~nm}$ (a320) and the absorption slope at $285 \mathrm{~nm}$ ( $\mathbf{S}_{285}$ ) for the five treatments (given in Fig. 1). Error bars represent the standard errors. The thin bars on the left of $\mathrm{T} 0$ values indicate the $95 \%$ confidence interval at $\mathrm{T} 0$ using the corresponding colours of the 
https://doi.org/10.5194/bg-2022-26

Preprint. Discussion started: 28 January 2022

(c) Author(s) 2022. CC BY 4.0 License. 3 days and inoculated with bacteria).

DIC, CDOM and DOC values were not statistically different between the two light treatments, with the exception of CDOM at day 8 (posthoc, $\mathrm{P}<0.0001$ ), and DOC at days 13 and 18 (posthoc, $\mathrm{P}<0.0126$ ). Significant increases in $\mathrm{S}_{285}$ (Fig. 2) were also observed in the light treatments, indicating a decline in DOM overall molecular size over time. There was a significant decreasing trend in $\mathrm{SUVA}_{254}$ during the experiment, but values did not get out of the 95\% confidence interval of T0 (data not shown). As for CDOM, there was an overall decrease in FDOM under light (Fig. 3).
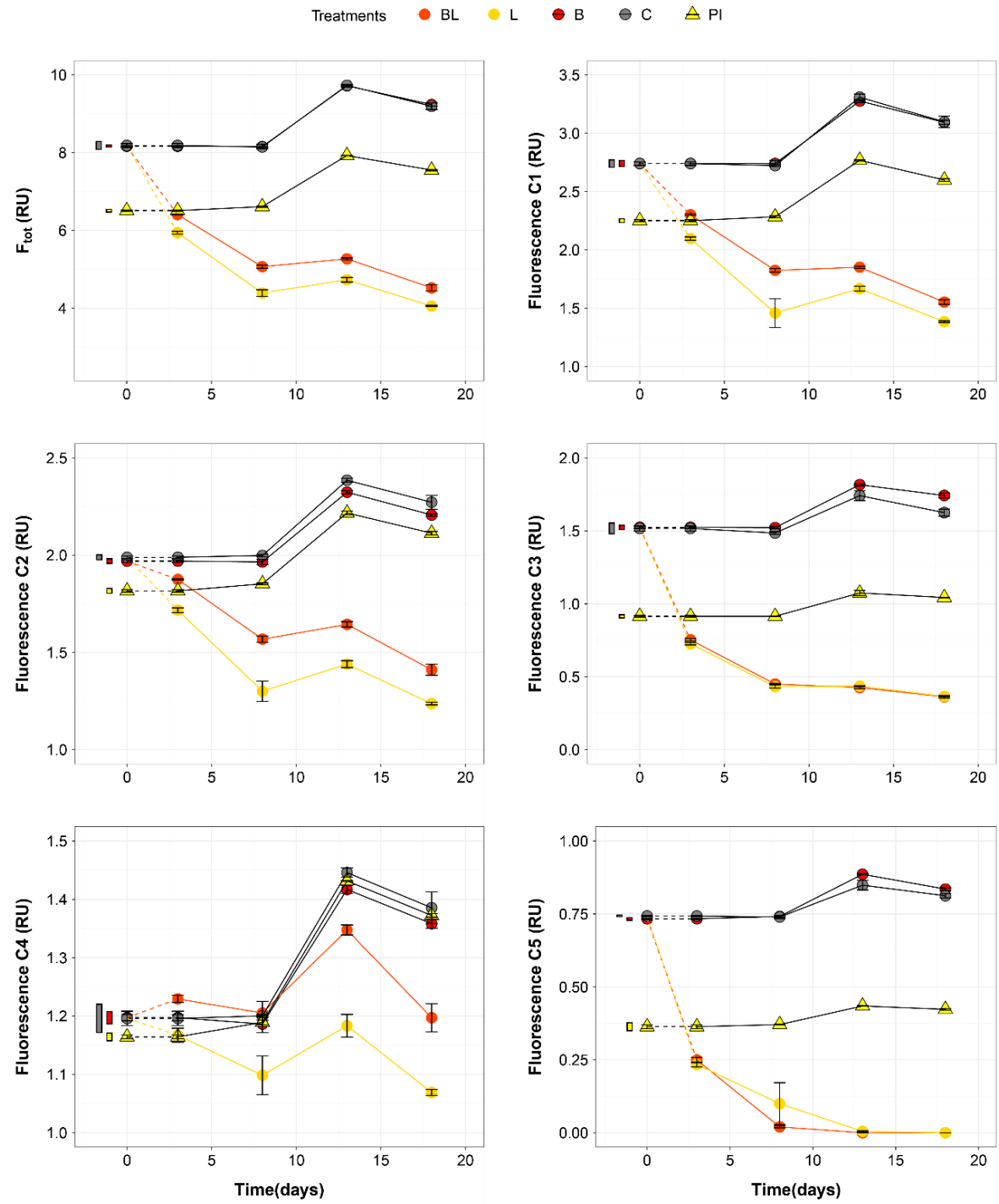
Figure 3. Temporal dynamics of the total fluorescence $\left(F_{\text {tot }}\right)$ and the five fluorescing components $(\mathrm{C1}-\mathrm{C5})$ over the 18 days of incubation for the five treatments (given in Fig. 1). Error bars represent the standard errors. The thin bars on the left of T0 values indicate the $95 \%$ confidence interval at T0 (colour codes as in Fig. 2 caption).

After 18 days, $\mathrm{F}_{\text {tot }}$ losses were $3.6 \mathrm{RU}$ (by 45\%) and $4.1 \mathrm{RU}$ (50\%) for BL and L, respectively. C1 and C3 contributed the most to these losses (around 30\% each), followed by $\mathrm{C} 2$ and $\mathrm{C} 5$. C5 completely disappeared after 13 days of light exposition. On the other hand, $\mathrm{C} 4$ did not vary much but still showed a significant decrease under

light exposure. The decreasing dynamic strongly slowed down starting from day 8 for almost all variables.

On the contrary to the dynamics observed under sunlight exposure, there were almost no changes over time for the dark treatments (B and C). Only at day 18, DIC was found significantly higher in C treatment by comparison to the rest of the incubation, and the DOC value was out of the $95 \%$ confidence interval of T0 (Figs. 1 and 2). Total DOC losses were 1.5 and $1.7 \mathrm{mgC} \mathrm{L}^{-1}$ for $\mathrm{B}$ and $\mathrm{C}$ treatments, respectively. A sudden increase in all fluorescent components was observed after day 8 (mean increase by 19\%) (Fig. 3). There was no overall difference in the measured variables for B and C treatments, except for DIC, DOC and C3 fluorescence.

The variables measured in the PI treatment showed responses that were comparable to those of the dark treatments, with limited or no changes in time (Table S4). FDOM components, except C5, significantly increased after 8 days (posthoc, $\mathrm{P}<0.0004$ ) in the same proportions as in treatments B and C (mean increase by 19\%). Over 18 days, there was a DOC loss of $1.1 \mathrm{mgC} \mathrm{L}^{-1}$ that was not reflected in CDOM (loss $<0.01 \mathrm{~m}^{-1}$ ). As expected, initial DOM properties in PI treatment such as DOC, $\mathrm{a}_{320}, \mathrm{~S}_{285}$ or $\mathrm{C} 1$ were close to day 3-values of $\mathrm{L}$ treatment since the preincubation with light lasted about 3 days (posthoc, $\mathrm{P}>0.30$ at day 3 ).

\subsection{Bacterial abundance (BA) and production (BP)}

The BA at T0 already indicated that sterility was not achieved by the $0.2 \mu \mathrm{m}$ filtration step (Table 1 ), and this initial population significantly increased in abundance over time in both $\mathrm{L}$ and $\mathrm{C}$ treatments (respectively 39 and 4 times more at day 18 compared to T0; Fig. 4). The most outstanding dynamic was obtained for the L treatment, with an overall growth of $1.5 \times 10^{5}$ cells $\mathrm{mL}^{-1} \mathrm{day}^{-1}$. This means it took about 8 days for BA in the $0.2 \mu \mathrm{m}$-filtered $\mathrm{L}$ treatment to reach the initial abundance observed in B and BL treatments, and by the end of the experiment, BA had reached $2.69 \times 10^{6}$ cells $\mathrm{mL}^{-1}$. The bacterial population that bypassed the $0.2-\mu \mathrm{m}$ filtration, or was airborne during filling the bottles, grew at a much slower pace in the control treatment $\left(0.1 \times 10^{5}\right.$ cells $\left.\mathrm{mL}^{-1} \mathrm{day}^{-1}\right)$, and tended to have a declining dynamic after day 13. The BA was rather stable in treatments with the original bacterial community (BL and B), with values still inside the $95 \%$ confidence interval of $\mathrm{T} 0$ at day 18 . However, bacteria remained overall more abundant in BL than in B treatment (posthoc, $\mathrm{P}<0.0001$ ). Growth in PI treatment was significant but $\mathrm{BA}$ remained stable between day 3 and day 18 . At the end of the incubation, there was more bacteria in PI than in $\mathrm{C}$ (posthoc, $\mathrm{P}=0.04$ ).

Bacterial production significantly increased from $\mathrm{T} 0$ in all treatments during the incubation (Fig. 5). The highest production rates were obtained for the $\mathrm{BL}$ treatment, reaching $1.11 \mu \mathrm{gC} \mathrm{L}^{-1} \mathrm{~h}^{-1}$ by the end of the incubation, equivalent to twice the production in the dark (B treatment) at the same moment. The exposition to sunlight and the presence of the initial community both contributed to the higher BP (Table S3). However, for treatments with a large reduction of the original bacterial abundance ( $\mathrm{L}$ and $\mathrm{C}$ ), the $\mathrm{BP}$ at day 18 was lower than at day 8 (posthoc, $\mathrm{P}=0.04$ ), which is particularly evident for the $\mathrm{L}$ treatment. For PI treatment, BP did not change significantly between day 8 and day 18 (posthoc, $\mathrm{P}=0.9957$ ). 


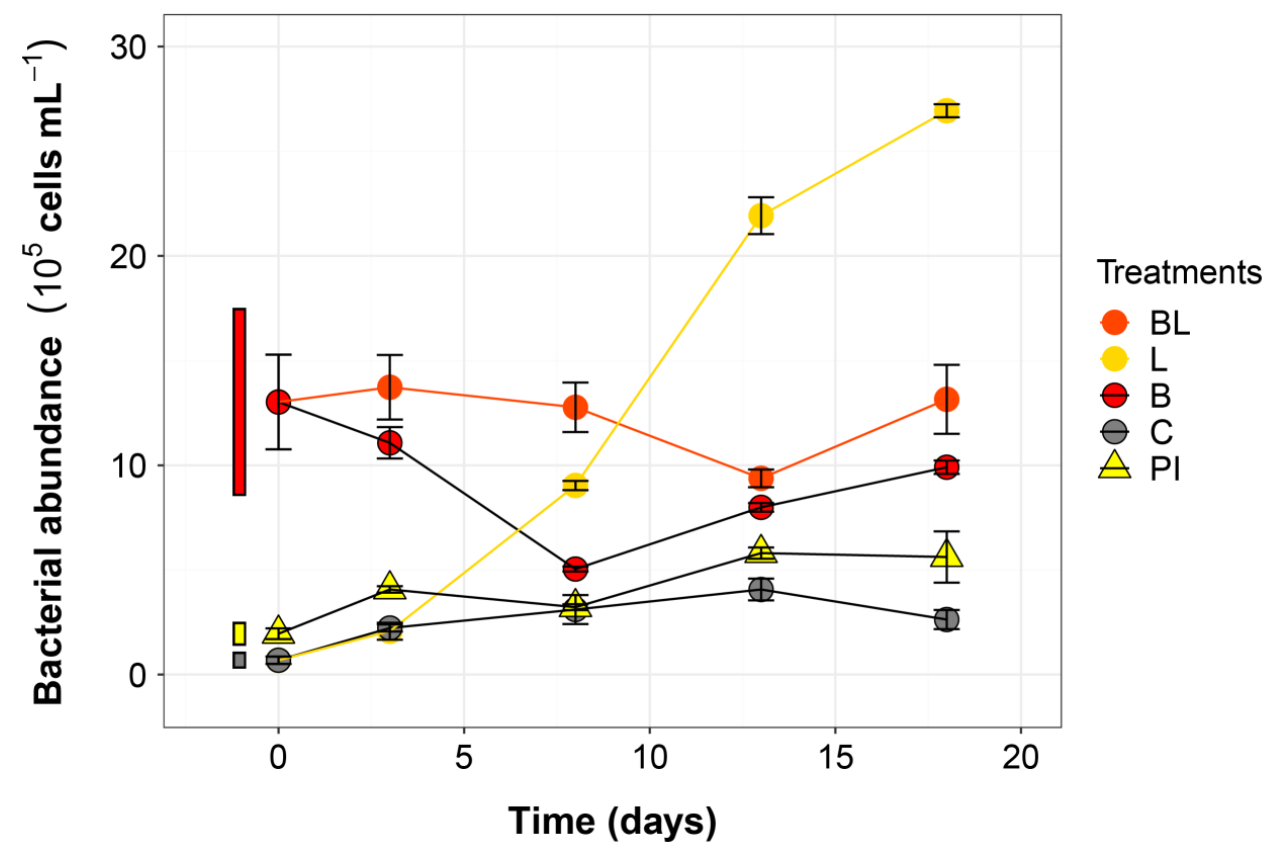

Figure 4. Bacterial abundance along the 18-day incubation for the five treatments (given in Fig. 1). Error bars represent the standard errors. The thin bars on the left of $\mathrm{TO}$ values indicate the $95 \%$ confidence interval at $\mathrm{TO}$ (colour codes as in Fig. 2 caption).

The normalization of BP by the bacterial abundance brought up another perspective to these data (Fig. 5). Exposure to sunlight was no longer a significant factor, and differences between treatments appeared smaller, especially at day 8 where the differences in BP were not significant (posthoc, $\mathrm{P}>0.09$ ). Nevertheless, it can be noted that the only treatment showing a continuously increasing trend was BL.

\subsection{Carbon losses and gains during the experiment}

Assessment of the carbon balance allowed to check whether the measured processes (DIC production, bacterial growth) were enough to describe the carbon transfers occurring in the incubation bottles (Fig. 6). In all treatments and at all times, the measured carbon loss (as a decrease in DOC) was always higher $(+58 \%$ to $+1214 \%)$ than the

measured carbon gain (as the sum of DIC and BP), even after maximizing BP in the calculation (i.e. by applying the highest rate obtained to all time periods of any specific treatment). BP gains thus represented on average 10\% and $38 \%$ of the total gain measured, respectively for the light treatments (BL and $\mathrm{L}$ ), and for the dark treatments (B, C and PI). Also, the uncertainty around the loss term was generally much higher than around the gain term (mean of 1.06 against $0.15 \mathrm{mgC} \mathrm{L}^{-1}$ ). However, the difference between losses (in DOC) and gains (in DIC and bacterial biomass) was clearly larger for the two light treatments: on average $3.6 \mathrm{mgC} \mathrm{L}^{-1}$ after 18 days of incubation, as compared to $0.8 \mathrm{mgC} \mathrm{L}^{-1}$ for the three other treatments (Fig. 6f, Wilcoxon test, $\mathrm{P}<0.0004$ ). Moreover, BL and L were characterized by a unique pattern in which carbon losses kept increasing, while carbon gains apparently reached a plateau from day 8 . 
https://doi.org/10.5194/bg-2022-26

Preprint. Discussion started: 28 January 2022

(c) Author(s) 2022. CC BY 4.0 License.
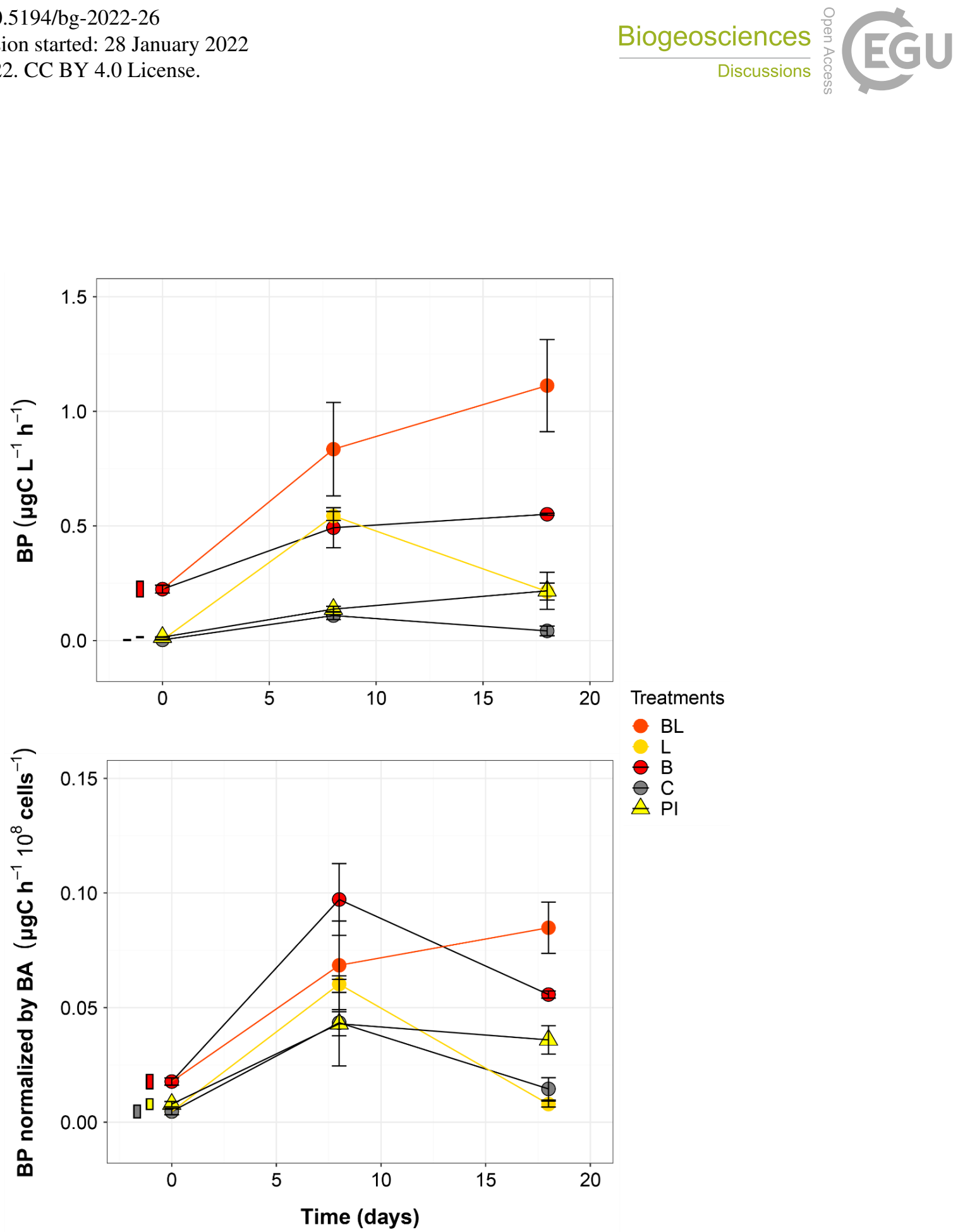

Treatments

- BL

L

$\ominus$

$\triangle \mathrm{PI}$

Figure 5. Bacterial production without (top) and with (bottom) normalization to cell abundance over the incubation period for the five treatments (given in Fig. 1). Error bars represent the standard errors. The thin bars on the left of T0 values indicate the $95 \%$ confidence interval at $\mathrm{TO}$ (colour codes as in Fig. 2 caption). 
https://doi.org/10.5194/bg-2022-26

Preprint. Discussion started: 28 January 2022

(c) Author(s) 2022. CC BY 4.0 License.

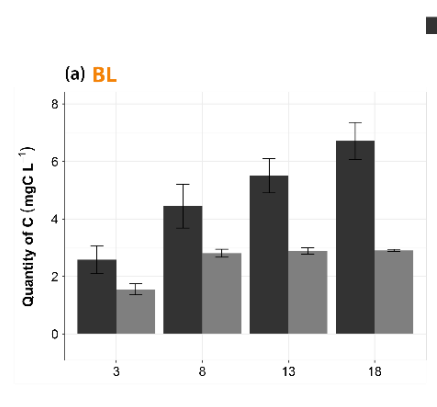

$\square$ Losses (DOC) $\square$ Gans (DIC + blomass) $\square$ Losses-Ganns difference
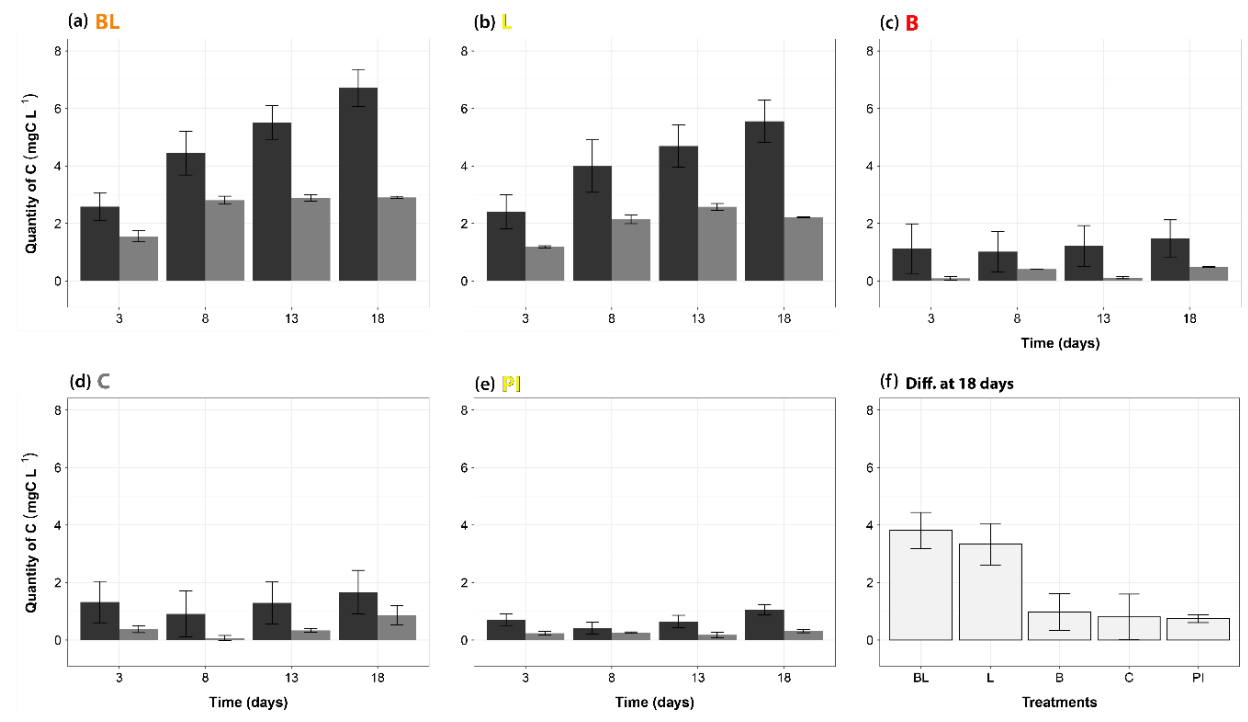

Figure 6. Mass balance of measured carbon transfers during the incubation, categorized as "losses" and "gains". Panels (a) to (e) correspond to treatments BL, L, B, C and PI respectively, and present the mass changes of carbon relative to T0 for days 3, 8, 13 and 18. Black bars represent the DOC losses (through sun mineralization, bacterial consumption, plus all other processes not directly measured), and grey bars represent gains of carbon as the sum of carbon increases in DIC and bacterial biomass. The bacterial biomass carbon gains were estimated for each time period using the highest BP value obtained for each treatment in order to evaluate the maximal potential carbon transfer into bacterial biomass. The panel (f) summarizes the difference between losses and gains for each treatment at the end of the incubation, potentially representing DOC flocculation but also other unmeasured processes like DOC conversion into carbon monoxide for the light treatments (see discussion). Error bars represent the standard errors.

\section{Discussion}

\subsection{Sunlight as a driver of DOM mineralization}

One of the main results of this study is the clear dominance of sunlight as a driver of DOM degradation and mineralization in the studied peatland thermokarst lake at the end of winter. In BL and L treatments, the same significant concurrent changes were observed: $\mathrm{CO}_{2}$ was produced while DOC, $\mathrm{CDOM}$ and FDOM aromatic fractions declined, along with a general decrease in DOM molecular weight (increase of $\mathrm{S}_{285}$ ). These changes were limited or absent in dark conditions.

Light absorption by CDOM cause a destruction of the chromophores. Optically, this translates into bleaching and the breakage of high-molecular weight molecules (Helms et al., 2008; Moran et al., 2000). When this photonmediated oxidation is complete, $\mathrm{CO}_{2}$ is produced and a corresponding carbon loss is going from DOC to gaseous state (Granéli et al., 1996). When the oxidation process is uncomplete, various moieties with different stages of oxidation accumulate in water, and their transformation does not result in DOC loss (e.g. Ward et al., 2014). The experiment here shows that both types of reactions occurred. About $4 \mathrm{mgC} \mathrm{L}^{-1}$ were lost over 18 days through the direct action of sunlight ( $\mathrm{L}$ treatment minus $\mathrm{C}$, DOC loss rate of $0.22 \mathrm{mgC} \mathrm{L}^{-1} \mathrm{day}^{-1}$ ). A certain fraction of this loss was certainly generated by the unexpected growth of bacteria in the $\mathrm{L}$ treatment, however a much larger fraction 
of this loss was likely due to direct photomineralization for two reasons. First, the DIC production was the highest over the first 3 days $\left(0.38 \mathrm{mM} \mathrm{day}^{-1}\right)$ when bacterial regrowth was still minor. Second, when using the highest BP rate measured in the $\mathrm{L}$ treatment $\left(0.54 \mu \mathrm{gC} \mathrm{L}^{-1} \mathrm{~h}^{-1}\right.$, measured at day 8$)$, we estimate that a maximum of $0.23 \mathrm{mgC}$ $\mathrm{L}^{-1}$ over the incubation period could have been lost through this biological pathway, representing about $6 \%$ of the DOC loss in L treatment. By comparison, $5 \mathrm{mgC} \mathrm{L}^{-1}$ were lost in the BL treatment (after subtraction of C treatment, DOC loss rate of $0.28 \mathrm{mgC} \mathrm{L}^{-1} \mathrm{day}^{-1}$ ). The difference between $\mathrm{BL}$ and $\mathrm{L}$ treatments can be attributed to the indirect action of sunlight favouring the bacterial consumption of DOC through the production of partially photooxidized biolabile substrates (at a conservative rate of $0.06 \mathrm{mgC} \mathrm{L}^{-1} \mathrm{day}^{-1}$ ). Overall, we can consider that most DOC lost in BL treatment was triggered by sunlight, with a maximum of $78 \%$ resulting from its direct action (such as full photoconversion into $\mathrm{CO}_{2}$ ) and a minimum of $22 \%$ resulting from its indirect action (such as bacterial consumption of photoproducts). The DOC loss in BL and L treatments measured over 18 days respectively represented 23\% and $18 \%$ of the initial DOC concentration. We systematically subtracted the DOC loss of the C treatment, considering it would include all DOC losses unrelated to light or bacteria (e.g. through adsorption or dark flocculation: see below). Even if there was a light regrowth of bacteria also in this control treatment, we considered it negligible as there was no measurable DIC production, and the maximum amount of carbon canalized to bacterial production over the incubation period was estimated at $0.05 \mathrm{mgC} \mathrm{L}^{-1}$ (using a BP of $0.11 \mu \mathrm{gC} \mathrm{L}^{-1} \mathrm{~h}^{-1}$, measured at day 8), representing less than $1 \%$ of the DOC loss in BL treatment.

Our results indicate that DOM from northern peatland thermokarst lakes is very sensitive to sunlight degradation, especially after ice melt, in accordance with results from studies on boreal waters. For example, the integrated $\mathrm{CO}_{2}$ photoproduction was 3.5 times larger in spring than in summer for three boreal lakes (Vachon et al., 2016). At a broader scale, Cory et al. (2014) estimated that about one third of $\mathrm{CO}_{2}$ production by arctic rivers and lakes results from direct photomineralization, and could be attributed to the combination of high DOM photoreactivity and low temperature (limiting respiration) at high latitudes. However, Shirokova et al. (2019), who incubated DOM from a Russian frozen peatland network reported the absence of measurable DOC loss over one month of sunlight exposure, and attributed this result to a dominance of refractory allochthonous DOM from soil and peat in this region. This difference suggests a variability in peatland DOM reactivity among regions, potentially related to different historical processing of the organic matter. Historical processing could differ prior to permafrost inception (Tank et al., 2020), or prior to sampling (Laurion et al., 2021). The sunlight dose received (historical dose in situ, or during an experiment) needs to be closely taken into account when comparing studies. A major difference between Shirokova et al. (2019) and our experiment is for instance related to the season when water was collected (late winter vs peaking summer), which likely had a major impact on DOM photolability. Seasonal variations have to be further quantified to make more accurate predictions on the effects of winter contraction associated to climate warming.

\subsection{The role of flocculation in the DOC loss}

In our experiment, DOC losses under sunlight were not fully recovered in the form of DIC or bacterial biomass, and the relative gap between carbon losses and gains was increasing over time (Fig. 6). After 18 days, no more than $51 \%$ of the DOC losses were actually recovered in the form of DIC (from direct photomineralization and photo-stimulated bacterial respiration), which corresponds to about only $10 \%$ of the initial DOC concentration. 
This necessarily implies the existence of other light-mediated processes. Part of the unaccounted DOC loss could have been transformed into carbon monoxide (not measured in the present study), another common photoproduct (Mopper et al., 2015; Moran and Zepp, 1997) that depends on the presence of certain DOM aromatic groups (Stubbins et al., 2008). Most importantly, the natural formation of flocs of organic matter (flocculation) could explain this gap. Several studies showed that sunlight is a triggering factor to the formation of particles and colloids, particularly in CDOM and iron-rich waters (Gao and Zepp, 1998; Helms et al., 2013; Mopper et al., 2015; Oleinikova et al., 2017; von Wachenfeldt et al., 2008). For example, von Wachenfeldt et al. (2008) reported that the synthesis of particulate organic matter from DOC of a sphagnum-dominated mire water almost reached 0.3 $\mathrm{mgC} \mathrm{L}^{-1} \mathrm{day}^{-1}$. It has also been shown that rising temperature can favour the transformation of DOC to flocs (Porcal et al., 2015; von Wachenfeldt et al., 2009). We indeed observed particles in filtered-water bottles but did not account for them quantitatively. In summary, photo-flocculation was likely occurring in our experimental water, which presented high DOC, CDOM and iron concentrations (Table S1) and was subject to high temperature peaks during the incubation (Fig. S1).

The DOC loss under B treatment (bacteria and small grazers, $1.5 \mathrm{mgC} \mathrm{L}^{-1}$ ) was similar to the one in the control treatment ( $5 \%$ of initial BA and no grazers, $1.7 \mathrm{mgC} \mathrm{L}^{-1}$ ), suggesting that in the absence of sunlight, carbon losses were not associated to bacterial activity. In fact, the similar gaps between carbon losses and gains in B and C treatments (Fig. 6, not showing a specific temporal trend) could be attributed to the adsorption of DOM molecules onto bottle walls (potentially quicker than flocculation). Helms et al. (2013) experimentally estimated that such adsorption was responsible for the loss of up to $0.08 \mathrm{mgC} \mathrm{L}^{-1} \mathrm{day}^{-1}$ (on $550 \mathrm{~mL}$ quartz bottles). They also reported that this phenomenon was apparently strengthened by sunlight exposure, so this potential adsorption may have been even stronger in BL and L treatments. At last, bacteria-mediated flocculation could also have happened during dark incubations. This has been observed in water from oligotrophic boreal lakes in winter, where the bacterial activity would have favoured the formation of detrital flocs from CDOM (von Wachenfeldt et al., 2009).

Our results suggest that flocculation may be important in peatland thermokarst lakes, and thus play a critical role in carbon burial. This has been highlighted as a main topic of interest related to the future of aquatic ecosystems affected by thawing permafrost (Vonk et al., 2015). Flocculation should be systematically quantified during experimental assays testing on the role of sunlight in carbon cycling. Other studies corroborate the idea that boreal lakes could be strong carbon sinks through sedimentation processes, especially in ecosystems with high allochthonous humic DOM (Guillemette et al., 2017; von Wachenfeldt and Tranvik, 2008).

\subsection{DOM biodegradation and bacterial dynamics in the dark treatments}

The quantitative and qualitative changes of DOM in dark treatments were insignificant and comparable among B, $\mathrm{C}$ and PI treatments (Fig. 2), despite different bacterial community size and activity, notably between B and the two other treatments (Fig. $4 \& 5$ ). This suggests that late winter DOM was refractory to biodegradation, at least over the incubation period. Communities were active in these treatments (BP > 0 and modest bacterial growth), but the insignificant DOC loss generated suggests a negligible transfer of carbon to bacterial growth and respiration $\left(\mathrm{CO}_{2}\right.$ production could not be detected). However, it is unclear what part of the DOM sustained bacteria activity as CDOM neither changed much (except for the small loss of CDOM observed in B treatment over the first 8 days, concurrent to an increase in BP; Fig. 2 and Fig. 5). Of course, we cannot exclude that winter DOM would be 
biodegraded over longer time-scales. For example, Vähätalo and Wetzel (2008) reported that wetland-origin DOM, apparently biorefractory over 14 days, was actually reduced by half over 2.5 years of dark incubation.

From an ecological perspective, we found that late-winter DOM in this thermokarst lake was recalcitrant to bacterial degradation, which means the system was mainly concentrating molecules at the lower end of the reactivity continuum described by Mostovaya et al. (2017). This is supported by the initial properties of this DOM pool, strongly dominated by aromatic compounds with a typical terrestrial signature (high $\mathrm{SUVA}_{254}$ and CDOM, only humic-like FDOM components with allochthonous features). Finding a recalcitrant DOM pool at the end of the winter is not surprising. As winter goes by, water gets more depleted in labile material, consumed first and foremost, while fresh inputs of carbon are impeded by the ice-cover, the frozen surrounding soils, and the absence of primary production in the lake and on land (Deshpande et al., 2016; Przytulska et al., 2016; Shirokova et al., 2021). Overall, this is consistent with studies on peatland water generally reporting low bacterial growth efficiencies (i.e. Berggren et al., 2007; Shirokova et al., 2019). By comparison, bacterial activity was clearly higher when supplied with fresh plant leachates (Shirokova et al., 2021). The abundance of low-quality substrates in peatland water may be related to the dominance of Sphagnum mosses at the study sites. These mosses are known to produce litter of poor organic matter quality that is decomposing slowly because their chemical structure holds large concentrations of phenolic, nonpolar and antimicrobial compounds (Turetsky, 2003).

Despite the absence of DOM consumption, microbial communities were relatively active and growing in the dark (Fig. 4 and Fig. 5). For example, the normalized BP in the B treatment was particularly high at day 8, and the BA substantially increased from T0 in PI and C treatments. Dark treatments were also characterized by a notable increase in the signal of all fluorescent components, starting after 8 days of incubation (Fig. 3). This increase presumably happened also in the light treatments BL and L, noticed in the slowing declines of fluorophores (sometimes, even a small increase). It is fairly acknowledged that bacteria can produce FDOM, and this has been broadly observed in boreal and arctic lakes (e.g. Berggren et al., 2020; Laurion et al., 2021). The study of Berggren et al. (2020) on 101 boreal lakes suggests the reciprocal dependence between microbial processes and DOM optical properties. Considering the concurrent increase in BP and FDOM, we assume that bacteria were responsible for this synthesis of fluorescent molecules. The five humic components identified here had mostly been described as terrestrial, but our results suggest that they could also be produced by aquatic bacteria (although in a lake strongly influenced by eroding soils). Finally, it is interesting to note that there was no parallel increase of CDOM (a $\mathrm{a}_{320}$ decreased), suggesting that chromophoric non-fluorescent DOM would have been transformed into FDOM. Lastly, it should be noted that the BP measured in the dark treatments is probably not representative of in situ latewinter production, where anoxia prevails and water temperature is close to $0^{\circ} \mathrm{C}$. The experimental water was oxygenated during the filtration steps (overall mean of $8.96 \pm 0.23 \mathrm{mgO}_{2} \mathrm{~L}^{-1}$ at $\mathrm{T} 0$ for all treatments) and the temperature regularly peaked around $30^{\circ} \mathrm{C}$ during the incubation (Fig. S1), exceeding the maximum temperature reached in situ in summer $\left(18^{\circ} \mathrm{C}\right.$ at the surface, Matveev et al., 2019). The bacterial production reported here was similar to what was measured from the same lake in summer (Deshpande et al., 2016), while studies on other thermokarst lakes of the region found strong differences between summer and winter production (Roiha et al., 2015). Nevertheless, our results suggest that the bacterial metabolism was more limited by the quality of DOM than by the environmental conditions (see below), in accordance with results from Bižić-Ionescu et al. (2014) who 
showed that carbon rather than temperature was the limiting factor on bacterial growth in a temperate oligotrophic lake in winter.

\subsection{The photochemical stimulation of bacteria}

The exposure to sunlight had a positive impact on the bacterial dynamics of this thermokarst lake. On one hand, when only a small proportion of the initial bacterial community was left ( $\sim 5 \%$, L treatment), sunlight exposure induced the exponential growth of these few bacteria, reaching about 10 times the abundance in the dark by the end of the incubation (C treatment; Fig. 4). The BP also increased in the first week but dropped at the end of the experiment (no measurements between days 8 and 18; Fig. 5), possibly indicating that this population was reaching a stationary phase in response to a decline in the photoproduction of high-quality substrates, expressed as a slowing rise in BA. On the other hand, sunlight induced a more persistent rise in BP for BL treatment, although the difference in BP was apparently linked to differences in population size (see normalized BP, Fig. 5b). Yet, the increase in BP did not translate into rising biomass in this treatment. This could be explained by the grazing pressure exerted on bacteria by small protists that were able to pass through the nominal $1.5 \mu \mathrm{m}$ filtration step (filters were indeed brittle during the filtration steps, and larger cracks may have existed, potentially related to the pre-burning step weakening the glass fibres). Nutrient enrichment experiments realized on summer water from the same lake also showed that BP was maintained or increased while BA dropped (Deshpande et al., 2016) suggesting an important top-down control of bacterial populations in this lake (Bégin and Vincent, 2017; Przytulska et al., 2016). Complex mechanisms involving the viral population could also control the size of the bacterial community facing important changes such as in spring. Girard et al. (2020) demonstrated that communities in SAS2A lake were active and seasonally shifting in response to the population dynamics of host organisms. Interestingly, this potential viral control would not have acted on the rising population observed in $\mathrm{L}$ treatment, potentially linked to the inhibiting action of UV radiation on viral activity.

The observed intensification of protein and cell synthesis under sunlight exposure indicates a photochemical conversion of part of the DOM into substrates readily available for bacterial growth, as it was previously described in the literature (e.g. Moran and Zepp, 1997). Most common photoproducts are organic acids, but other low molecular weight compounds containing essential nutrients could also be involved (Pullin et al., 2004; Vähätalo et al., 2003; Wetzel et al., 1995). For example, Xie et al. (2012) reported the photoproduction of ammonium from DOM. The higher BP in BL treatment clearly indicates that the bacterial community was benefiting from the photoproduction of essential compounds. However, the insignificant difference in DIC production between BL and $\mathrm{L}$ treatments, especially between 0 and 3 days when the $\mathrm{BA}$ in $\mathrm{L}$ was still negligible, suggests that most $\mathrm{CO}_{2}$ was directly photoproduced and not resulting from respiration of this fast-growing population.

Results also suggest that the initial sunlight exposure of 2 days in PI treatment was not sufficient to substantially stimulate microbial metabolism. The fact that the initial community was small (inoculum) is not likely to be the reason, because $\mathrm{L}$ treatment demonstrated that the initial size of the community was not a strong determinant of its activity in the following days. We hypothesize that the limiting factor was rather the limited amount of photolabile compounds produced over the 2 days of sunlight pre-exposure. CDOM decreased by $14 \%$ and $\mathrm{S}_{285}$ increased by $10 \%$, indicating that photodegradation happened (Table 1), but photoproducts may have been consumed rapidly and the stimulation turned down as soon as the water was placed back in the dark. The 
superposition of $\mathrm{C}$ and $\mathrm{L}$ curves in the first 3 days could also indicate that a minimum length of sunlight exposure was needed to produce a boosting effect on bacteria. This lag could reflect the adaptation time needed by the community to respond to a change in the quality of the carbon resource. Ward et al. (2017) demonstrated that shifts in substrates availability were driving deep shifts in bacterial gene expression and composition, translating into time lags in bacterial metabolism. These effects would be occurring in a water column intermittently mixing that is generating a complex pattern of sunlight exposure (Matveev et al., 2019).

Achieving sterility is a difficult task and we argue that BA should always be controlled in such experiments. Not considering this could lead to interpretation biases. Filtration artefacts can impact short-term biolability assays through their effects on bacterial abundance, composition and predation as demonstrated for waters draining from peatlands in the Netherlands (Dean et al., 2018). Although we achieved to reduce the initial BA by $95 \%$ in $\mathrm{L}$ treatment, it took about 8 days for these bacteria to overtake the abundance observed in BL treatment. Although the effect of sunlight could not be isolated completely, the experiment clearly demonstrated the efficient role of sunlight on bacterial growth and carbon mineralization. We further noted that cells with a higher DNA content seemed to be particularly abundant in the light treatments at the end of the incubation (Fig. S3). A taxonomic characterization of these bacterial populations appearing on the cytograms (examples given in Fig. S4) is needed to better understand the effects of sunlight on the bacterial cycling of permafrost carbon.

\subsection{Significance at the lake scale}

The strong impact of sunlight reported here needs to be considered in the specific context of thermokarst lakes. In such humic lakes, only surface layers receive photochemically active photons. For example, Vähätalo et al. (2000) calculated that $90 \%$ of photomineralization happened in the top meter of a humic lake, with UV radiation contributing to $77 \%$ of this mineralization. Similarly, the study from Koehler et al. (2014) based on 1086 Swedish lakes concluded that $95 \%$ of the depth-integrated DIC photoproduction happened in the upper $0.8 \mathrm{~m}$ of the water column. Attenuation coefficients were estimated from downwelling irradiance profiles realized in SAS2A in August 2016 (unpublished data) with a multispectral radiometer (Satlantic Inc., now owned by Sea-bird scientific). In July, 90\% of incident photons were attenuated at 5, 14 and $23 \mathrm{~cm}$ respectively for wavelengths 380,443 and $491 \mathrm{~nm}$. Therefore, most of direct photomineralization in this lake is occurring in the first centimetres of the water column. In our experiment, degradation was constrained to a $7.3 \mathrm{~cm}$-depth (diameter of bottles floating under a thin layer of transparent tap water) which makes it representative of a typical exposure at the very surface of the lake. Previous studies indicate that thermokarst lakes in this area are strongly stratified most of the year, with brief mixing periods in spring and autumn which depend on lake morphology (Matveev et al., 2019). Notably, the small size of these lakes and their high DOM content impede on a complete spring turnover, where only top layers get mixed for a few days until summer stratification establishes. Partial mixing then occurs on a daily basis at night. This mixing regime generates conditions where sunlight can only reach surface layers, but partial mixing at night likely brings fresh DOM at the surface on a diurnal basis. Thus, the experimental exposure of the same DOM molecules for 18 days may have underestimated the photodegradation potentially taking place in situ, where substrate limitation is less likely to occur. On the other hand, incident irradiance during the experiment down south was 30 to $103 \%$ higher than at the study site (depending on the year - Fig. S1), likely causing an acceleration in photochemical decomposition over the first days of the incubation, but this was followed by the plateauing of 
certain proxies (e.g., DIC, bacterial growth in $\mathrm{L}$ treatment) suggesting the limitation of substrates in the absence of mixing renewal.

At last, the study by Deshpande et al. (2016) highlighted the importance of attached bacteria in SAS2A lake, where more than $70 \%$ of BA and BP was associated to particles larger than $3 \mu \mathrm{m}$. As most particles were removed in the present experiment (filtration either through 1.5 or $0.2 \mu \mathrm{m}$ ), it is likely that bacterioplankton respiration, growth and DOM degradation were underestimated. Moreover, our experiment provides information on DOM biodegradation potentially happening in the upper oxygenated layers, but it does not address bacterial activity in deeper anoxic layers of the lake. To fully account on the importance of dark bacterial mineralization relative to photomineralization, experiments will have to include particle-attached flora and respect the anoxic conditions prevailing in these systems. The present study can only underline that photomineralization is an efficient process accelerating DOM processing in epilimnetic waters of thermokarst lakes.

\section{Conclusion}

615 Through this work, we have shown that winter DOM collected from a thermokarst lake in a subarctic peatland is having a high potential of photoreactivity at ice-off, and that the bacterial community originating from the water was strongly stimulated by sunlight. About $5.0 \mathrm{mgC} \mathrm{L}^{-1}$ (23\% of initial DOC concentration) were lost over 18 days when bacteria and sunlight were both at play. Results indicate that (1) direct effects of sunlight (78\% of this DOC loss) were much larger than indirect effects ( $22 \%$ of the DOC loss, stimulation of bacterial consumption through the synthesis of labile photoproducts), (2) photomineralization $\left(\mathrm{CO}_{2}\right.$ production by direct or indirect effects) did not account for more than $51 \%$ of the DOC losses ( $10 \%$ of initial DOC concentration), and (3) most of the remaining DOC loss was likely associated to photo-flocculation. The positive effect of sunlight on the bacterial community was particularly demonstrated by the outstanding regrowth of the population left in L treatment (even after the $0.2 \mu \mathrm{m}$ filtration). Without sunlight stimulation, no detectable DOC or CDOM losses could be attributed to the sole action of bacteria, yet they remain relatively active in the dark and produced FDOM. The highly-colored aromatic DOM found in these lakes at the end of winter was quite refractory to biodegradation but particularly sensitive to sunlight. Our work suggests that sunlight is an important mediator of $\mathrm{CO}_{2}$ emission and carbon burial in peatland thermokarst lakes after the ice cover melts. The next step will be to quantify this cycling at the lake scale by taking into account the natural conditions prevailing in spring, including local irradiance, temperature and oxygen concentration. A direct quantification of DOM flocculation and its mediation by sunlight are also needed. Finally, the inclusion of particle-attached microorganisms and the characterization of bacterial communities during this seasonal transition (from dark anoxic conditions under the ice cover to varying exposure to sunlight and oxygen in the diurnally-mixed surface layer of the lake) would help to improve our understanding of climate change effects on the carbon cycling in this important class of lakes.

635 Data availability. The dataset of the experience and related temperature-irradiance metadata are deposited in Nordicana D at the DOI: 10.5885/45759XX-9ED4BB6AE585446C (Mazoyer et al., 2022).

Supplement link. This article contains a supplement information. 
Authors contribution. The field campaign was conducted by IL and MR. FM designed and performed the experiment with the help of IL. FM analyzed the data and wrote the manuscript under the supervision of IL and MR.

Competing interests. The authors declare that they have no conflict of interest.

Acknowledgements. We thank Martin Pilote, Alex Matveev, Joao Canario, Alice Lévesque, and our Cri guide, Thomas Shem, for their help in the field, and also Gilles Guérin for his logistical assistance to set up the experiment on the lab roof. We acknowledge Jérôme Comte for his advice and flow cytometer, and Audrey-Anne Boutin for her help with cytometric analyses. We thank Maxime Wauthy and François Guillemette for their help during the building of the PARAFAC model. Finally, we are greatly thankful to Mathieu Cusson for his advices on the statistical analyses. The project was supported by a seeding grant from the CEN Hudsonie21 program, NSERC discovery and northern supplement grants to IL, along with a scholarship from EnviroNorth CREATE program to FM.

\section{References}

Arlen-Pouliot, Y. and Bhiry, N.: Palaeoecology of a palsa and a filled thermokarst pond in a permafrost peatland, subarctic Québec, Canada, The Holocene, 15(3), 408-419, doi:10.1191/0959683605hl818rp, 2005.

Bégin, P. N. and Vincent, W. F.: Permafrost thaw lakes and ponds as habitats for abundant rotifer populations, Arct. Sci., 3(2), 354-377, doi:10.1139/as-2016-0017, 2017.

655 Berggren, M., Laudon, H. and Jansson, M.: Landscape regulation of bacterial growth efficiency in boreal freshwaters, Global Biogeochem. Cycles, 21, doi:10.1029/2006GB002844, 2007.

Berggren, M., Gudasz, C., Guillemette, F., Hensgens, G., Ye, L. and Karlsson, J.: Systematic microbial production of optically active dissolved organic matter in subarctic lake water, Limnol. Oceanogr., 65(5), 951-961, doi:10.1002/lno.11362, 2020.

Bhiry, N., Delwaide, A., Allard, M., Bégin, Y., Filion, L., Lavoie, M., Nozais, C., Payette, S., Pienitz, R., SaulnierTalbot, É. and Vincent, W. F.: Environmental change in the Great Whale River region, Hudson Bay: Five decades of multidisciplinary research by Centre d'études nordiques (CEN), Écoscience, 18(3), 182-203, doi:10.2980/183-3469, 2011.

Biskaborn, B. K., Smith, S. L., Noetzli, J., Matthes, H., Vieira, G., Streletskiy, D. A., Schoeneich, P., Romanovsky, 665 V. E., Lewkowicz, A. G., Abramov, A., Allard, M., Boike, J., Cable, W. L., Christiansen, H. H., Delaloye, R., Diekmann, B., Drozdov, D., Etzelmüller, B., Grosse, G., Guglielmin, M., Ingeman-Nielsen, T., Isaksen, K., Ishikawa, M., Johansson, M., Johannsson, H., Joo, A., Kaverin, D., Kholodov, A., Konstantinov, P., Kröger, T., Lambiel, C., Lanckman, J. P., Luo, D., Malkova, G., Meiklejohn, I., Moskalenko, N., Oliva, M., Phillips, M., Ramos, M., Sannel, A. B. K., Sergeev, D., Seybold, C., Skryabin, P., Vasiliev, A., Wu, Q., Yoshikawa, K., 670 Zheleznyak, M. and Lantuit, H.: Permafrost is warming at a global scale, Nat. Commun., 10(1), 1-11, doi:10.1038/s41467-018-08240-4, 2019.

Bižić-Ionescu, M., Amann, R. and Grossart, H. P.: Massive regime shifts and high activity of heterotrophic bacteria in an ice-covered lake, PLoS One, 9(11), 1-17, doi:10.1371/journal.pone.0113611, 2014. 
Block, B. D., Denfeld, B. A., Stockwell, J. D., Flaim, G., Grossart, H. P. F., Knoll, L. B., Maier, D. B., North, R. and Hampton, S. E.: The unique methodological challenges of winter limnology, Limnol. Oceanogr. Methods, 17(1), 42-57, doi:10.1002/lom3.10295, 2019.

Centre for northern studies (CEN): Climate station data from Whapmagoostui-Kuujjuarapik Region in Nunavik, Quebec, Canada, v. 1.5 (1987-2019). Nordicana D4, 2020a.

Centre for northern studies (CEN): Unpublished data, 2020b.

Cole, J. J., Prairie, Y. T., Caraco, N. F., McDowell, W. H., Tranvik, L. J., Striegl, R. G., Duarte, C. M., Kortelainen, P., Downing, J. A., Middelburg, J. J. and Melack, J.: Plumbing the Global Carbon Cycle: Integrating Inland Waters into the Terrestrial Carbon Budget, Ecosystems, 10(1), 172-185, doi:10.1007/s10021-006-9013-8, 2007.

Cory, R. M., Crump, B. C., Dobkowski, J. A. and Kling, G. W.: Surface exposure to sunlight stimulates CO2 release from permafrost soil carbon in the Arctic, Proc. Natl. Acad. Sci., 110(9), 3429-3434, doi:10.1073/pnas.1214104110, 2013.

Cory, R. M., Ward, C. P., Crump, B. C. and Kling, G. W.: Sunlight controls water column processing of carbon in arctic fresh waters, Science, 345(6199), 925-928, doi:10.1126/science.1253119, 2014.

Dean, J. F., van Hal, J. R., Dolman, A. J., Aerts, R. and Weedon, J. T.: Filtration artefacts in bacterial community composition can affect the outcome of dissolved organic matter biolability assays, Biogeosciences, 15(23), 71417154, doi:10.5194/bg-15-7141-2018, 2018.

Denfeld, B. A., Baulch, H. M., del Giorgio, P. A., Hampton, S. E. and Karlsson, J.: A synthesis of carbon dioxide and methane dynamics during the ice-covered period of northern lakes, Limnol. Oceanogr. Lett., 3(3), 117-131, doi:10.1002/lol2.10079, 2018.

Deshpande, B. N., Crevecoeur, S., Matveev, A. and Vincent, W. F.: Bacterial production in subarctic peatland lakes enriched by thawing permafrost, Biogeosciences, 13(15), 4411-4427, doi:10.5194/bg-13-4411-2016, 2016. Elder, C. D., Xu, X., Walker, J., Schnell, J. L., Hinkel, K. M., Townsend-Small, A., Arp, C. D., Pohlman, J. W., Gaglioti, B. V. and Czimczik, C. I.: Greenhouse gas emissions from diverse Arctic Alaskan lakes are dominated by young carbon, Nat. Clim. Chang., 8(2), 166-171, doi:10.1038/s41558-017-0066-9, 2018.

Gao, H. and Zepp, R. G.: Factors Influencing Photoreactions of Dissolved Organic Matter in a Coastal River of the Southeastern United States, Environ. Sci. Technol., 32(19), 2940-2946, doi:10.1021/es9803660, 1998.

del Giorgio, P. A. and Bouvier, T. C.: Linking the physiologic and phylogenetic successions in free-living bacterial communities along an estuarine salinity gradient, Limnol. Oceanogr., 47(2), 471-486, doi:10.4319/lo.2002.47.2.0471, 2002.

705 Girard, C., Langlois, V., Vigneron, A., Vincent, W. F. and Culley, A. I.: Seasonal Regime Shift in the Viral Communities of a Permafrost Thaw Lake, Viruses, 12(11), doi:10.3390/v12111204, 2020.

Granéli, W., Lindell, M. and Tranvik, L.: Photo-oxidative production of dissolved inorganic carbon in lakes of different humic content, Limnol. Oceanogr., 41(4), 698-706, doi:10.4319/lo.1996.41.4.0698, 1996.

Groeneveld, M., Tranvik, L., Natchimuthu, S. and Koehler, B.: Photochemical mineralisation in a boreal brown 710 water lake: Considerable temporal variability and minor contribution to carbon dioxide production, Biogeosciences, 13(13), 3931-3943, doi:10.5194/bg-13-3931-2016, 2016.

Guillemette, F., von Wachenfeldt, E., Kothawala, D. N., Bastviken, D. and Tranvik, L. J.: Preferential 
sequestration of terrestrial organic matter in boreal lake sediments, J. Geophys. Res. Biogeosciences, 122(4), 863874, doi:10.1002/2016JG003735, 2017.

Hampton, S. E., Galloway, A. W. E., Powers, S. M., Ozersky, T., Woo, K. H., Batt, R. D., Labou, S. G., O’Reilly, C. M., Sharma, S., Lottig, N. R., Stanley, E. H., North, R. L., Stockwell, J. D., Adrian, R., Weyhenmeyer, G. A., Arvola, L., Baulch, H. M., Bertani, I., Bowman, L. L., Carey, C. C., Catalan, J., Colom-Montero, W., Domine, L. M., Felip, M., Granados, I., Gries, C., Grossart, H.-P., Haberman, J., Haldna, M., Hayden, B., Higgins, S. N., Jolley, J. C., Kahilainen, K. K., Kaup, E., Kehoe, M. J., MacIntyre, S., Mackay, A. W., Mariash, H. L., McKay, R. M., Nixdorf, B., Nõges, P., Nõges, T., Palmer, M., Pierson, D. C., Post, D. M., Pruett, M. J., Rautio, M., Read, J. S., Roberts, S. L., Rücker, J., Sadro, S., Silow, E. A., Smith, D. E., Sterner, R. W., Swann, G. E. A., Timofeyev, M. A., Toro, M., Twiss, M. R., Vogt, R. J., Watson, S. B., Whiteford, E. J. and Xenopoulos, M. A.: Ecology under lake ice, edited by J. Grover, Ecol. Lett., 20(1), 98-111, doi:10.1111/ele.12699, 2017.

Helms, J. R., Stubbins, A., Ritchie, J. D., Minor, E. C., Kieber, D. J. and Mopper, K.: Absorption spectral slopes and slope ratios as indicators of molecular weight, source, and photobleaching of chromophoric dissolved organic matter, Limnol. Oceanogr., 53(3), 955-969, doi:10.4319/lo.2008.53.3.0955, 2008.

Helms, J. R., Mao, J., Schmidt-Rohr, K., Abdulla, H. and Mopper, K.: Photochemical flocculation of terrestrial dissolved organic matter and iron, Geochim. Cosmochim. Acta, 121, 398-413, doi:10.1016/j.gca.2013.07.025, 2013.

730 Hughes-Allen, L., Bouchard, F., Laurion, I., Séjourné, A., Marlin, C., Hatté, C., Costard, F., Fedorov, A. and Desyatkin, A.: Seasonal patterns in greenhouse gas emissions from thermokarst lakes in Central Yakutia (Eastern Siberia), Limnol. Oceanogr., 55(S1), S150-S164, doi:10.1002/lno.11665, 2021.

Jansen, J., Thornton, B. F., Jammet, M. M., Wik, M., Cortés, A., Friborg, T., MacIntyre, S. and Crill, P. M.: Climate-Sensitive Controls on Large Spring Emissions of CH4 and CO2 From Northern Lakes, J. Geophys. Res. Biogeosciences, 124(7), 2379-2399, doi:10.1029/2019JG005094, 2019.

Kirchman, D., K'nees, E. and Hodson, R.: Leucine incorporation and its potential as a measure of protein synthesis by bacteria in natural aquatic systems, Appl. Environ. Microbiol., 49(3), 599-607, 1985.

Koehler, B., Landelius, T., Weyhenmeyer, G. A., Machida, N. and Tranvik, L. J.: Sunlight-induced carbon dioxide emissions from inland waters, Global Biogeochem. Cycles, 28(7), 696-711, doi:10.1002/2014GB004850, 2014.

Laurion, I., Vincent, W. F., MacIntyre, S., Retamal, L., Dupont, C., Francus, P. and Pienitz, R.: Variability in greenhouse gas emissions from permafrost thaw ponds, Limnol. Oceanogr., 55(1), 115-133, doi:10.4319/lo.2010.55.1.0115, 2010.

Laurion, I., Massicotte, P., Mazoyer, F., Negandhi, K. and Mladenov, N.: Weak mineralization despite strong processing of dissolved organic matter in Eastern Arctic tundra ponds, Limnol. Oceanogr., 66(S1), S47-S63, doi:10.1002/lno.11634, 2021.

Matveev, A., Laurion, I., Deshpande, B. N., Bhiry, N. and Vincent, W. F.: High methane emissions from thermokarst lakes in subarctic peatlands, Limnol. Oceanogr., 61, S150-S164, doi:10.1002/lno.10311, 2016.

Matveev, A., Laurion, I. and Vincent, W. F.: Winter Accumulation of Methane and its Variable Timing of Release from Thermokarst Lakes in Subarctic Peatlands, J. Geophys. Res. Biogeosciences, 124, 3521-3535, doi:10.1029/2019JG005078, 2019.

Mazoyer, F., Laurion, I. and Rautio, M.: Dissolved organic matter and bacterial data, along with associated 
temperature-irradiance metadata for a degradation experiment using winter water from a subarctic thermokarstic peatland lake in Nunavik, Québec, Canada, Nordicana D, doi:10.5885/45759XX-9ED4BB6AE585446C, 2022.

Mopper, K., Kieber, D. J. and Stubbins, A.: Marine Photochemistry of Organic Matter: Processes and Impacts, in Biogeochemistry of Marine Dissolved Organic Matter, edited by D. A. Hansell and C. A. Carlson, pp. 389-450, Elsevier., 2015.

Moran, M. A. and Zepp, R. G.: Role of photoreactions in the formation of biologically labile compounds from dissolved organic matter, Limnol. Oceanogr., 42(6), 1307-1316, doi:10.4319/1o.1997.42.6.1307, 1997.

Moran, M. A., Sheldon, W. M. and Zepp, R. G.: Carbon loss and optical property changes during long-term photochemical and biological degradation of estuarine dissolved organic matter, Limnol. Oceanogr., 45(6), 12541264, doi:10.4319/lo.2000.45.6.1254, 2000.

Mostovaya, A., Hawkes, J. A., Koehler, B., Dittmar, T. and Tranvik, L. J.: Emergence of the Reactivity Continuum of Organic Matter from Kinetics of a Multitude of Individual Molecular Constituents, Environ. Sci. Technol., 51(20), 11571-11579, doi:10.1021/acs.est.7b02876, 2017.

Murphy, K. R., Butler, K. D., Spencer, R. G. M., Stedmon, C. A., Boehme, J. R. and Aiken, G. R.: Measurement of Dissolved Organic Matter Fluorescence in Aquatic Environments: An Interlaboratory Comparison, Environ. Sci. Technol., 44(24), 9405-9412, doi:10.1021/es102362t, 2010.

Murphy, K. R., Stedmon, C. A., Graeber, D. and Bro, R.: Fluorescence spectroscopy and multi-way techniques. PARAFAC, Anal. Methods, 5(23), 6557, doi:10.1039/c3ay41160e, 2013.

Murphy, K. R., Stedmon, C. A., Wenig, P. and Bro, R.: OpenFluor- an online spectral library of auto-fluorescence by organic compounds in the environment, Anal. Methods, 6(3), 658-661, doi:10.1039/C3AY41935E, 2014.

Murphy, K. R., Timko, S. A., Gonsior, M., Powers, L. C., Wünsch, U. J. and Stedmon, C. A.: Photochemistry Illuminates Ubiquitous Organic Matter Fluorescence Spectra, Environ. Sci. Technol., 52, 11243-11250, doi:10.1021/acs.est.8b02648, 2018.

Obernosterer, I. and Benner, R.: Competition between biological and photochemical processes in the mineralization of dissolved organic carbon, Limnol. Oceanogr., 49(1), 117-124, doi:10.4319/lo.2004.49.1.0117, 2004.

Olefeldt, D., Goswami, S., Grosse, G., Hayes, D., Hugelius, G., Kuhry, P., McGuire, A. D., Romanovsky, V. E., Sannel, A. B. K., Schuur, E. A. G. and Turetsky, M. R.: Circumpolar distribution and carbon storage of thermokarst landscapes, Nat. Commun., 7(1), 13043, doi:10.1038/ncomms13043, 2016.

Oleinikova, O. V., Drozdova, O. Y., Lapitskiy, S. A., Demin, V. V., Bychkov, A. Y. and Pokrovsky, O. S.: Dissolved organic matter degradation by sunlight coagulates organo-mineral colloids and produces low-molecular weight fraction of metals in boreal humic waters, Geochim. Cosmochim. Acta, 211, 97-114, doi:10.1016/j.gca.2017.05.023, 2017.

Pickard, A. E., Heal, K. V., McLeod, A. R. and Dinsmore, K. J.: Temporal changes in photoreactivity of dissolved organic carbon and implications for aquatic carbon fluxes from peatlands, Biogeosciences, 14(7), 1793-1809, doi:10.5194/bg-14-1793-2017, 2017.

Porcal, P., Dillon, P. J. and Molot, L. A.: Temperature Dependence of Photodegradation of Dissolved Organic Matter to Dissolved Inorganic Carbon and Particulate Organic Carbon, PLoS One, 10(6), doi:10.1371/journal.pone.0128884, 2015. 
Prèskienis, V., Laurion, I., Bouchard, F., Douglas, P. M. J., Billett, M. F., Fortier, D. and Xu, X.: Seasonal patterns in greenhouse gas emissions from lakes and ponds in a High Arctic polygonal landscape, Limnol. Oceanogr., 66(S1), S117-S141, doi:10.1002/lno.11660, 2021.

Przytulska, A., Comte, J., Crevecoeur, S., Lovejoy, C., Laurion, I. and Vincent, W. F.: Phototrophic pigment diversity and picophytoplankton in permafrost thaw lakes, Biogeosciences, 13(1), 13-26, doi:10.5194/bg-13-132016, 2016.

Pullin, M. J., Bertilsson, S., Goldstone, J. V. and Voelker, B. M.: Effects of sunlight and hydroxyl radical on dissolved organic matter: Bacterial growth efficiency and production of carboxylic acids and other substrates, Limnol. Oceanogr., 49(6), 2011-2022, doi:10.4319/lo.2004.49.6.2011, 2004.

Roiha, T., Laurion, I. and Rautio, M.: Carbon dynamics in highly heterotrophic subarctic thaw ponds, Biogeosciences, 12, 7223-7237, 2015.

Schuur, E. A. G., McGuire, A. D., Schädel, C., Grosse, G., Harden, J. W., Hayes, D. J., Hugelius, G., Koven, C. D., Kuhry, P., Lawrence, D. M., Natali, S. M., Olefeldt, D., Romanovsky, V. E., Schaefer, K., Turetsky, M. R., Treat, C. C. and Vonk, J. E.: Climate change and the permafrost carbon feedback, Nature, 520, 171-179, doi:10.1038/nature14338, 2015.

Sepulveda-Jauregui, A., Walter Anthony, K. M., Martinez-Cruz, K., Greene, S. and Thalasso, F.: Methane and carbon dioxide emissions from 40 lakes along a north-south latitudinal transect in Alaska, Biogeosciences, 12(11), 3197-3223, doi:10.5194/bg-12-3197-2015, 2015.

Shirokova, L. S., Chupakov, A. V., Zabelina, S. A., Neverova, N. V., Payandi-Rolland, D., Causserand, C., Karlsson, J. and Pokrovsky, O. S.: Humic surface waters of frozen peat bogs (permafrost zone) are highly resistant to bio- and photodegradation, Biogeosciences, 16, 2511-2526, doi:10.5194/bg-16-2511-2019, 2019.

Shirokova, L. S., Chupakov, A. V., Ivanova, I. S., Moreva, O. Y., Zabelina, S. A., Shutskiy, N. A., Loiko, S. V. and Pokrovsky, O. S.: Lichen, moss and peat control of C, nutrient and trace metal regime in lakes of permafrost peatlands, Sci. Total Environ., 782, 146737, doi:10.1016/j.scitotenv.2021.146737, 2021.

Smith, D. and Azam, F.: A simple, economical method for measuring bacterial protein synthesis rates in seawater using 3H-leucine, Mar. Microb. food webs, 6(2), 107-114, 1992.

Sobek, S., Tranvik, L. J. and Cole, J. J.: Temperature independence of carbon dioxide supersaturation in global lakes, Global Biogeochem. Cycles, 19(GB2003), doi:10.1029/2004GB002264, 2005.

Stedmon, C. A., Markager, S. and Bro, R.: Tracing dissolved organic matter in aquatic environments using a new approach to fluorescence spectroscopy, Mar. Chem., 82(3-4), 239-254, doi:10.1016/S0304-4203(03)00072-0, 2003.

Stubbins, A., Hubbard, V., Uher, G., Law, C. S., Upstill-Goddard, R. C., Aiken, G. R. and Mopper, K.: Relating Carbon Monoxide Photoproduction to Dissolved Organic Matter Functionality, Environ. Sci. Technol., 42(9), 3271-3276, doi:10.1021/es703014q, 2008.

825 Tank, S. E., Vonk, J. E., Walvoord, M. A., McClelland, J. W., Laurion, I. and Abbott, B. W.: Landscape matters: Predicting the biogeochemical effects of permafrost thaw on aquatic networks with a state factor approach, Permafr. Periglac. Process., 31(3), 358-370, doi:10.1002/ppp.2057, 2020.

Turetsky, M. R.: The Role of Bryophytes in Carbon and Nitrogen Cycling, Bryologist, 106(3), 395-409, 2003.

Vachon, D., Lapierre, J. and del Giorgio, P. A.: Seasonality of photochemical dissolved organic carbon 
mineralization and its relative contribution to pelagic CO 2 production in northern lakes, J. Geophys. Res. Biogeosciences, 121(3), 864-878, doi:10.1002/2015JG003244, 2016.

Vachon, D., Solomon, C. T. and del Giorgio, P. A.: Reconstructing the seasonal dynamics and relative contribution of the major processes sustaining $\mathrm{CO} 2$ emissions in northern lakes, Limnol. Oceanogr., 62(2), 706-722, doi:10.1002/lno.10454, 2017.

Vähätalo, A. V. and Wetzel, R. G.: Long-term photochemical and microbial decomposition of wetland-derived dissolved organic matter with alteration of 13C:12C mass ratio, Limnol. Oceanogr., 53(4), 1387-1392, doi:10.4319/lo.2008.53.4.1387, 2008.

Vähätalo, A. V., Salkinoja -Salonen, M., Taalas, P. and Salonen, K.: Spectrum of the quantum yield for photochemical mineralization of dissolved organic carbon in a humic lake, Limnol. Oceanogr., 45(3), 664-676, doi:10.4319/lo.2000.45.3.0664, 2000.

Vähätalo, A. V., Salonen, K. M. and Wetzel, R. G.: Photochemical transformation of allochthonous organic matter provides bioavailable nutrients in a humic lake, Arch. für Hydrobiol., 156(3), 287-314, doi:10.1127/00039136/2003/0156-0287, 2003.

Vincent, W. F., Lemay, M. and Allard, M.: Arctic permafrost landscapes in transition: towards an integrated Earth system approach, Arct. Sci., 3(2), 39-64, doi:10.1139/as-2016-0027, 2017.

Vonk, J. E., Tank, S. E., Bowden, W. B., Laurion, I., Vincent, W. F., Alekseychik, P., Amyot, M., Billet, M. F., Canário, J., Cory, R. M., Deshpande, B. N., Helbig, M., Jammet, M., Karlsson, J., Larouche, J., MacMillan, G., Rautio, M., Walter Anthony, K. M. and Wickland, K. P.: Reviews and syntheses: Effects of permafrost thaw on Arctic aquatic ecosystems, Biogeosciences, 12, 7129-7167, doi:10.5194/bg-12-7129-2015, 2015.

von Wachenfeldt, E. and Tranvik, L. J.: Sedimentation in Boreal Lakes-The Role of Flocculation of Allochthonous Dissolved Organic Matter in the Water Column, Ecosystems, 11, 803-814, doi:10.1007/s10021008-9162-z, 2008.

von Wachenfeldt, E., Sobek, S., Bastviken, D. and Tranvik, L. J.: Linking allochthonous dissolved organic matter and boreal lake sediment carbon sequestration: The role of light-mediated flocculation, Limnol. Oceanogr., 53(6), 2416-2426, doi:10.4319/lo.2008.53.6.2416, 2008.

von Wachenfeldt, E., Bastviken, D. and Tranvika, L. J.: Microbially induced flocculation of allochthonous dissolved organic carbon in lakes, Limnol. Oceanogr., 54(5), 1811-1818, doi:10.4319/lo.2009.54.5.1811, 2009.

Ward, C. P., Sleighter, R. L., Hatcher, P. G. and Cory, R. M.: Insights into the complete and partial photooxidation of black carbon in surface waters, Environ. Sci. Process. Impacts, 16(4), 721-731, doi:10.1039/C3EM00597F, 2014.

Ward, C. P., Nalven, S. G., Crump, B. C., Kling, G. W. and Cory, R. M.: Photochemical alteration of organic carbon draining permafrost soils shifts microbial metabolic pathways and stimulates respiration, Nat. Commun., 8(772), doi:10.1038/s41467-017-00759-2, 2017.

Weishaar, J. L., Aiken, G. R., Bergamaschi, B. A., Fram, M. S., Fujii, R. and Mopper, K.: Evaluation of Specific

Ultraviolet Absorbance as an Indicator of the Chemical Composition and Reactivity of Dissolved Organic Carbon, Environ. Sci. Technol., 37(20), 4702-4708, doi:10.1021/es030360x, 2003.

Wetzel, R. G., Hatcher, P. G. and Bianchi, T. S.: Natural photolysis by ultraviolet irradiance of recalcitrant dissolved organic matter to simple substrates for rapidbacterial metabolism, Limnol. Oceanogr., 40(8), 1369-1380, 
https://doi.org/10.5194/bg-2022-26

Preprint. Discussion started: 28 January 2022

(c) Author(s) 2022. CC BY 4.0 License.

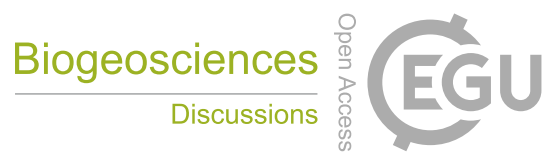

doi:10.4319/lo.1995.40.8.1369, 1995 .

870 Wik, M., Varner, R. K., Anthony, K. W., MacIntyre, S. and Bastviken, D.: Climate-sensitive northern lakes and ponds are critical components of methane release, Nat. Geosci., 9(2), 99-105, doi:10.1038/ngeo2578, 2016.

Xie, H., Bélanger, S., Song, G., Benner, R., Taalba, A., Blais, M., Tremblay, J.-É. and Babin, M.: Photoproduction of ammonium in the southeastern Beaufort Sea and its biogeochemical implications, Biogeosciences, 9, 30473061, doi:10.5194/bg-9-3047-2012, 2012.

875 